\title{
Kynurenic acid and cancer: facts and controversies
}

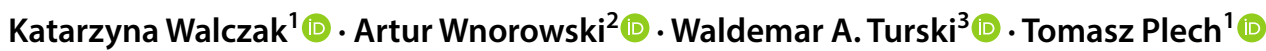

Received: 12 March 2019 / Revised: 30 September 2019 / Accepted: 8 October 2019 / Published online: 28 October 2019 (c) The Author(s) 2019

\begin{abstract}
Kynurenic acid (KYNA) is an endogenous tryptophan metabolite exerting neuroprotective and anticonvulsant properties in the brain. However, its importance on the periphery is still not fully elucidated. KYNA is produced endogenously in various types of peripheral cells, tissues and by gastrointestinal microbiota. Furthermore, it was found in several products of daily human diet and its absorption in the digestive tract was evidenced. More recent studies were focused on the potential role of KYNA in carcinogenesis and cancer therapy; however, the results were ambiguous and the biological activity of KYNA in these processes has not been unequivocally established. This review aims to summarize the current views on the relationship between KYNA and cancer. The differences in KYNA concentration between physiological conditions and cancer, as well as KYNA production by both normal and cancer cells, will be discussed. The review also describes the effect of KYNA on cancer cell proliferation and the known potential molecular mechanisms of this activity.
\end{abstract}

Keywords Cancer therapy $\cdot$ Proliferation $\cdot$ Cell cycle $\cdot$ GPR35 $\cdot$ AhR

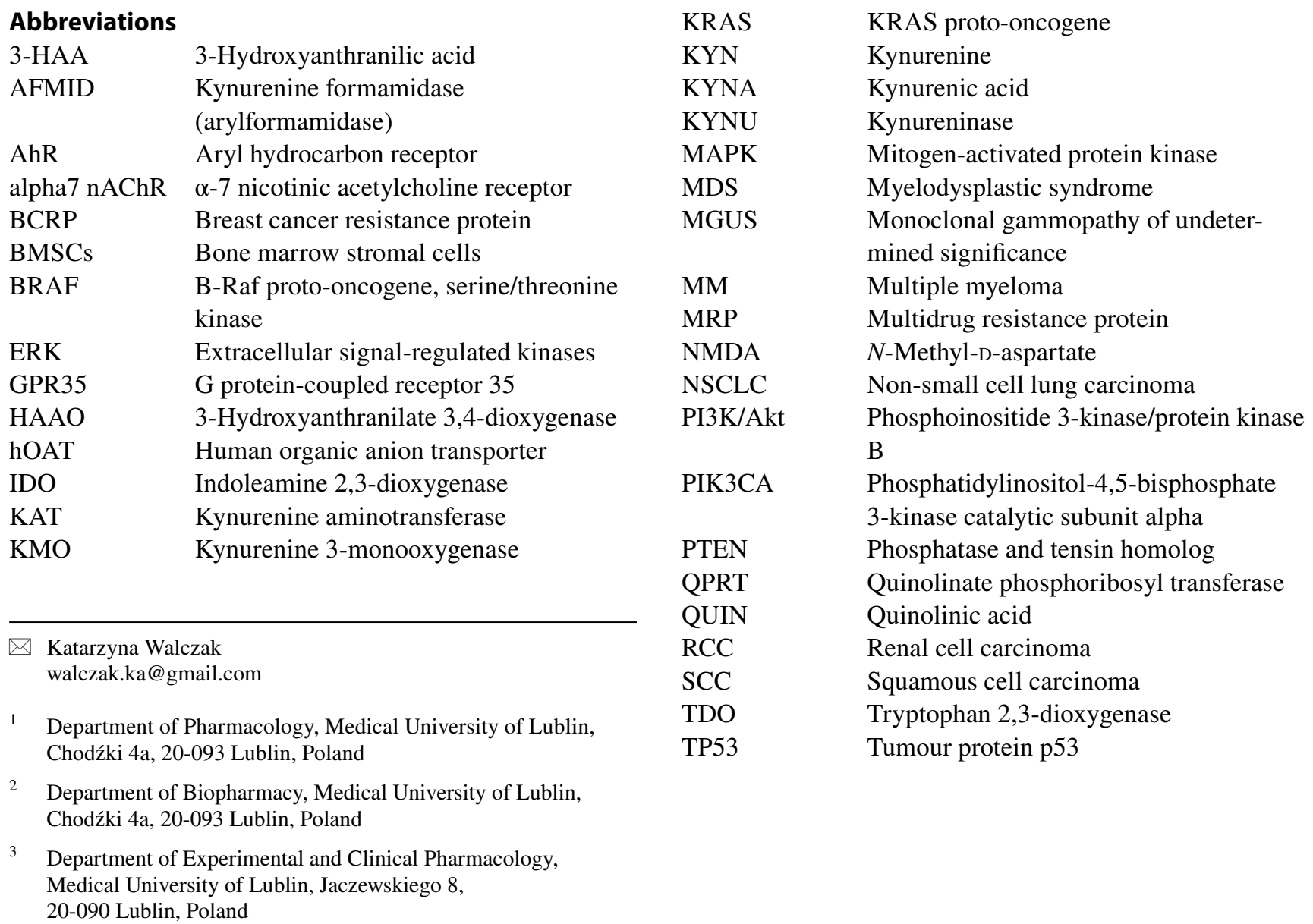




\section{Introduction}

Tryptophan is a precursor to many biologically active compounds in addition to its irreplaceable role in the process of protein biosynthesis. The kynurenine pathway is the principal route of catabolism of tryptophan, leading to the formation of the important redox cofactor nicotinamide adenine dinucleotide $\left(\mathrm{NAD}^{+}\right)$and several biologically active metabolites. However, tryptophan is also metabolized along the serotonin pathway leading to the biosynthesis of neuroactive substances: serotonin and melatonin. Importantly, it is also a substrate for gut bacterial production of indoles which are potentially involved in signalling between microbiota and innate immune system (Fig. 1) [1-3].

Previous studies have suggested that deregulation of the kynurenine pathway may lead to cancer progression through decreasing the effectiveness of the antitumour immune response (reviewed in $[4,5]$ ). The contribution of enzymes involved in tryptophan degradation: indoleamine 2,3-dioxygenase (IDO) and tryptophan 2,3-dioxygenase (TDO) has been previously discussed (reviewed in $[4,5]$ ). Expression of IDO1 is considered as a negative prognostic marker in several types of cancer including colon cancer, melanoma, haematological and gynaecological malignancies [6]. Similarly, expression of TDO in cancer cells may promote tumour progression in melanoma, glioma, gynaecological malignancies, lung cancer, renal and bladder cancers (reviewed in [5]). Moreover, the contribution of selected tryptophan metabolites including kynurenine (KYN), quinolinic acid (QUIN) and 3-hydroxyanthranilic acid (3-HAA) in the progression of tumours has been previously presented (reviewed in [4]). However, the potential role in the process of carcinogenesis of another endogenous metabolite of tryptophan-kynurenic acid (KYNA) has not been fully reviewed.

KYNA is produced enzymatically from the key intermediate in the tryptophan catabolic pathway-KYN $[7,8]$. Initial studies concerning the biological role of KYNA in the central nervous system revealed its neuroprotective and anticonvulsant properties based on receptor interactions [9-13]. Recent studies also underlined the potential role of KYNA in cognitive and memory impairments [14, 15]. However, KYNA is endogenously produced by several types of cells and tissues (brain tissue [16], retina [17]), and was detected in physiological fluids including urine, serum, amniotic fluid [18], milk [19], cerebrospinal fluid [16], synovial fluid [20], saliva [21], gastric juice, bile, pancreatic juice [22], mucus of rat small intestine [23], mucus of pig colon [22] and mucus aspirated from the human caecum or colon ascendens [24]. Importantly, KYNA was also found in several products of the daily human diet and medicinal herbs [25, 26]. The highest concentration was reported in honeybee

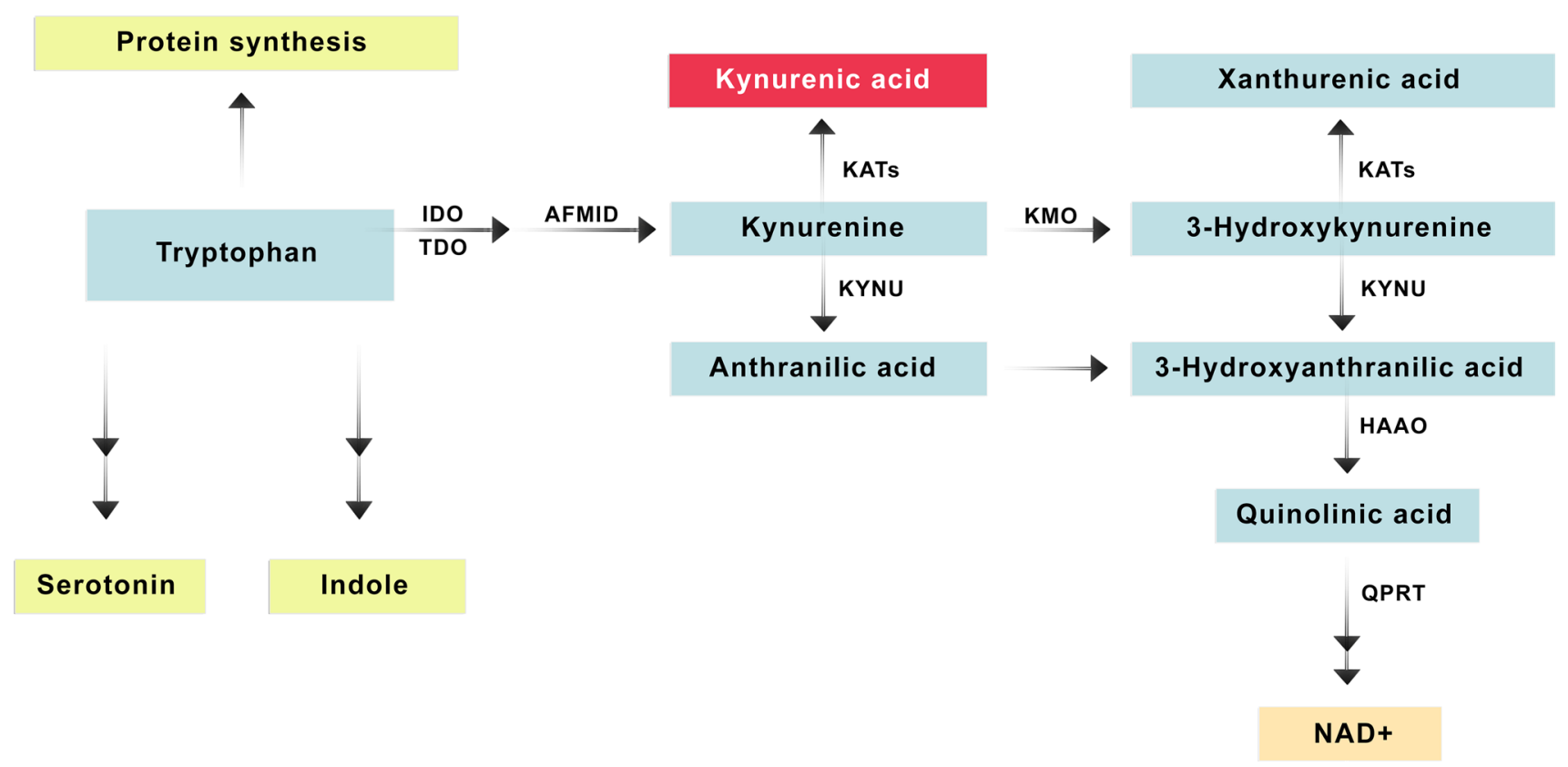

Fig. 1 The kynurenine pathway of tryptophan degradation. The selected enzymes of the kynurenine pathway are shown in a simplified scheme. AFMID kynurenine formamidase (arylformamidase), $H A A O$ 3-hydroxyanthranilate 3,4-dioxygenase, IDO indoleamine2,3-dioxygenase, KATs kynurenine aminotransferases [includes four isoenzymes: KAT I (KYAT1), KAT II (AADAT), KAT III (KYAT3), KAT IV (GOT2)], KMO kynurenine-3-monooxygenase, $K Y N U$ kynureninase, $Q P R T$ quinolinate phosphoribosyl transferase, TDO tryptophan 2,3-dioxygenase, $N A D$ nicotinamide adenine dinucleotide 
products and some fresh vegetables, including broccoli and potato [25]. Furthermore, previous studies have indicated that KYNA is absorbed from the intestine into the blood stream and reaches high concentrations in the liver and kidneys [25]. Even though the role of KYNA in physiological and pathological processes in the brain has been excessively studied, its importance on the periphery is still not fully elucidated. Previous studies indicated anti-inflammatory [27, 28], analgesic [29], antiulcerative [30-32], antiatherogenic [33], antioxidative [34] and hepatoprotective [35] properties of KYNA. More recent studies are focused on the potential role of KYNA in carcinogenesis and therapy, however, the results are ambiguous and the biological activity of KYNA in these processes has not been unequivocally established.

\section{KYNA content in cancer tissue and body fluids}

There are several studies focused on the KYNA content in various types of cancer (Table 1), which revealed some differences in KYNA concentration between cancer and physiological conditions. It was confirmed that KYNA is present in the colon adenocarcinoma [36], glioblastoma [37], renal cell carcinoma (RCC) [38] and oral squamous cell carcinoma (SCC) [39] tumour tissue. The highest KYNA concentration was reported in the colon adenocarcinoma [36], and a comparable amount of KYNA was detected in glioblastoma [37] and RCC [38] tumours, but KYNA content in oral SCC tissue was significantly lower [39]. Interestingly, there are ambiguous data concerning the differences in KYNA content in tumour and healthy tissue. KYNA concentration was considerably higher in the colon adenocarcinoma and oral SCC than in healthy colon mucosa [36] and oral mucosa [39]. On the other hand, there are some data presenting an inverted relationship. Walczak et al. [38] reported that KYNA concentration was considerably lower in RCC than in healthy renal tissue (Table 1).

KYNA was detected in the serum of patients diagnosed with cancer in concentrations that ranged from 21.3 to $250 \mathrm{nM}$ depending on the type of cancer [36, 40-44]. Higher KYNA concentration in serum in comparison to healthy population was observed in blood disorders, such as monoclonal gammopathy of undetermined significance (MGUS), representing premalignant conditions [41], multiple myeloma (MM) [41] and myelodysplastic syndrome (MDS) [44]. An elevated KYNA concentration was also detected in the serum of patients diagnosed with colon adenocarcinoma [36]. Interestingly, an elevated serum KYNA level was also associated with the invasiveness of lung cancer. Lung adenocarcinoma is considered as more aggressive than other types of non-small cell lung cancer. Sagan et al. [43] reported that the KYNA level in the serum of patients with lung adenocarcinoma was significantly higher than in lung SCC. Moreover, further studies indicated that circulating KYNA level was higher in non-small cell lung carcinoma (NSCLC) patients than in controls and its concentration level correlated with the stage of cancer progression since nodal involvement is considered as a negative prognostic factor (Table 1). The authors suggested a potent role of KYNA as a marker for non-invasive discrimination between $\mathrm{NO}$ and $\mathrm{N}+$ patients in NSCLC [45].

Additionally, an increased KYNA concentration was observed in bone marrow plasma of MGUS and MM patients [41]. Interestingly, the KYNA level in the bone marrow plasma of MGUS patients was significantly higher than in the MM group [41] (Table 1).

On the other hand, Fotopoulou et al. [42] observed in patients with primary cervical cancer a more than twofold decrease of serum KYNA concentration in comparison to a control (healthy) group. A similar effect was noted for patients diagnosed with glioblastoma [40]. KYNA concentration in plasma from glioblastoma patients was significantly lower than in plasma from healthy volunteers (Table 1) [40]. However, the reason for this phenomenon has not been clarified. Taking into consideration the increase in the activation of the kynurenine pathway (KYN/TRP ratio) along with a decrease in the concentration of neuroactive metabolites including KYNA in glioblastoma patient plasma compared to controls [40], it cannot be excluded that cancer cells change the route of kynurenine pathway to produce more effectively $\mathrm{NAD}^{+}$as a source of energy for their excessive metabolic processes.

There are a few studies concerning the potential influence of cancer on KYNA urinary excretion, as this tryptophan metabolite is mainly excreted from the body with urine. Fujinaga et al. [46] reported increased KYNA urinary excretion in a group of males diagnosed with bladder cancer. However, most studies did not confirm any relationship between KYNA excretion and bladder or kidney cancer [47, 48]. Additionally, no correlation between bladder cancer grade and KYNA content in urine was found [47]. Early studies also excluded the potential role of KYNA in the process of carcinogenesis in mouse bladder [49]. Similarly, Davis et al. [50] did not report any differences in KYNA urinary excretion between breast cancer patients and healthy subjects. On the other hand, there are some data suggesting that elevated KYNA urinary excretion after L-tryptophan loading may be considered as a potential diagnostic marker for some types of cancer [46, 47, 50-52]. Gailani et al. [51] reported increased urinary excretion of KYNA in $25 \%$ of patients diagnosed with bladder cancer after alimentary administration of L-tryptophan. These results were confirmed in the later studies by Fujinaga et al. [46]. KYNA level after L-tryptophan loading was also elevated in urine of breast cancer patients, demonstrating increased level of two or more tryptophan 
Table 1 Content of KYNA in tumour tissue, blood and urine from patients with cancer

\begin{tabular}{|c|c|c|c|c|}
\hline \multirow[t]{2}{*}{ Cancer/type } & \multirow[t]{2}{*}{ Tissue } & \multicolumn{2}{|l|}{ KYNA content } & \multirow[t]{2}{*}{ References } \\
\hline & & Cancer & Equivalent healthy tissue/fluid & \\
\hline Glioblastoma & Tumour & $\begin{array}{l}100.3 \mathrm{pmol} / \mathrm{g} \text { wet } \\
\text { weight } \sim 100.3 \mathrm{nM}^{\mathrm{c}}\end{array}$ & - & [37] \\
\hline Colon adenocarcinoma & Tumour & $\begin{array}{l}169.39 \mathrm{pmol} / \mathrm{g} \text { wet } \\
\text { weight } 169.39 \mathrm{nM}^{\mathrm{c}}\end{array}$ & $\begin{array}{l}80.13 \mathrm{pmol} / \mathrm{g} \text { wet } \\
\text { weight } \sim 80.13 \mathrm{nM}^{\mathrm{c}}\end{array}$ & [36] \\
\hline Renal cell carcinoma (RCC) & Tumour & $\begin{array}{l}115.5 \mathrm{pmol} / \mathrm{g} \text { wet } \\
\text { weight } \sim 115.5 \mathrm{nM}^{\mathrm{c}}\end{array}$ & $\begin{array}{l}379.7 \mathrm{pmol} / \mathrm{g} \text { wet } \\
\text { weight } \sim 379.7 \mathrm{nM}^{\mathrm{c}}\end{array}$ & [38] \\
\hline $\begin{array}{l}\text { Oral squamous cell carcinoma } \\
\text { (SCC) }\end{array}$ & Tumour & $15.85 \mathrm{nM}$ & $12.75 \mathrm{nM}$ & [39] \\
\hline Colon adenocarcinoma & Serum & $37.52 \mathrm{nM}$ & $26.44 \mathrm{nM}$ & [36] \\
\hline Lung cancer, adenocarcinoma & Serum & $107.1 \mathrm{nM}$ & - & [43] \\
\hline Lung cancer, squamous cell & Serum & $82.1 \mathrm{nM}$ & - & [43] \\
\hline Lung cancer, large cell & Serum & $86.2 \mathrm{nM}$ & - & [43] \\
\hline $\begin{array}{l}\text { Lung cancer, mixed and undiffer- } \\
\text { entiated }\end{array}$ & Serum & $69.5 \mathrm{nM}$ & - & [43] \\
\hline NSCLC & Serum & $93.60 \mathrm{nM}$ & $31.40 \mathrm{nM}$ & [45] \\
\hline Primary cervical cancer & Serum & $250 \mathrm{nM}$ & $550 \mathrm{nM}$ & [42] \\
\hline Myelodysplastic syndrome (MDS) & Serum & $\begin{array}{l}\text { No data-serum KYNA level } \\
\text { higher compared with healthy } \\
\text { control }\end{array}$ & - & [44] \\
\hline $\begin{array}{l}\text { Monoclonal gammopathy of unde- } \\
\text { termined significance (MGUS) } \\
\text { (premalignant condition) }\end{array}$ & Peripheral blood plasma & $87.42 \mathrm{nM}$ & $31.58 \mathrm{nM}$ & [41] \\
\hline Multiple myeloma (MM) & Peripheral blood plasma & $59.23 \mathrm{nM}$ & $31.58 \mathrm{nM}$ & [41] \\
\hline Glioblastoma (GBM) & Plasma & $21.3 \mathrm{nM}$ & $52.89 \mathrm{nM}$ & [40] \\
\hline $\begin{array}{l}\text { Monoclonal gammopathy of unde- } \\
\text { termined significance (MGUS) } \\
\text { (premalignant condition) }\end{array}$ & Bone marrow plasma & $78.41 \mathrm{nM}$ & $35.62 \mathrm{nM}$ & [41] \\
\hline Multiple myeloma (MM) & Bone marrow plasma & $53.92 \mathrm{nM}$ & $35.62 \mathrm{nM}$ & [41] \\
\hline Bladder cancer & Urine & $\begin{array}{l}\text { Higher excretion of kynurenic acid } \\
\text { in males }\end{array}$ & - & [46] \\
\hline Bladder cancer & Urine & No difference & $14.1 \mu \mathrm{mol} / 24 \mathrm{~h}$ & [48] \\
\hline Bladder cancer & Urine & $\begin{array}{l}14.13 \mu \mathrm{mol} / 24 \mathrm{~h} \text { (grades } 1-2) ; \\
12.53 \mu \mathrm{mol} / 24 \mathrm{~h} \text { (grades } 3-4)\end{array}$ & - & [47] \\
\hline Prostate cancer & Urine & $29.9 \mathrm{mg} / \mathrm{L}^{*} \sim 158 \mu \mathrm{M}$ & $41.6 \mathrm{mg} / \mathrm{L} * \sim 220 \mu \mathrm{M}$ & [53] \\
\hline $\begin{array}{l}\text { Breast cancer, 'normal breast } \\
\text { cancer'a }\end{array}$ & Urine & $11.6 \mu \mathrm{mol} / 24 \mathrm{~h}$ & $12.9 \mu \mathrm{mol} / 24 \mathrm{~h}$ & [50] \\
\hline $\begin{array}{l}\text { Breast cancer, 'abnormal breast } \\
\text { cancer'a }\end{array}$ & Urine & $13.5 \mu \mathrm{mol} / 24 \mathrm{~h}$ & $12.9 \mu \mathrm{mol} / 24 \mathrm{~h}$ & [50] \\
\hline Breast cancer, 'without new sites'b & Urine & $11.0 \mu \mathrm{mol} / 24 \mathrm{~h}$ & - & [47] \\
\hline Breast cancer, 'with new sites' ${ }^{\text {b }}$ & Urine & $11.55 \mu \mathrm{mol} / 24 \mathrm{~h}$ & - & [47] \\
\hline Human colon carcinoma & $\begin{array}{l}\text { Mucus from caecum or colon } \\
\text { ascendens }\end{array}$ & $269.40 \mathrm{nM}$ & $82.22 \mathrm{nM}$ & [24] \\
\hline Adenoma tubulovillosum & $\begin{array}{l}\text { Mucus from caecum or colon } \\
\text { ascendens }\end{array}$ & $200.50 \mathrm{nM}$ & $82.22 \mathrm{nM}$ & [24] \\
\hline Adenoma tubulare & $\begin{array}{l}\text { Mucus from caecum or colon } \\
\text { ascendens }\end{array}$ & $243.50 \mathrm{nM}$ & $82.22 \mathrm{nM}$ & [24] \\
\hline
\end{tabular}

*Statistically insignificant

${ }^{a}$ Breast cancer patients were divided into two groups: 'abnormal breast cancer patients' - patients demonstrating increased level of two or more tryptophan metabolites in comparison to control and 'normal breast cancer patients'-patients demonstrating increased level of no or one tryptophan metabolite in comparison to control

bBreast cancer patients were divided into two groups: 'with new sites'-patients with conclusive evidence of cancer at new sites, e.g., lung, ovaries, brain and bone and 'without new sites'-patients without evidence of cancer at new sites

${ }^{\mathrm{c}}$ Assuming $1 \mathrm{~g}$ wet weight $\sim 1 \mathrm{~mL}$ 
metabolites in comparison to control [50]. Although there was no correlation between breast cancer stage and basal KYNA urinary excretion, breast cancer patients with conclusive evidence of cancer at new sites, e.g., lung, ovaries, brain and bone, were characterized by elevated KYNA excretion after L-tryptophan administration [47]. Additionally, Gailani et al. [52] reported an increased urinary excretion of KYNA in $18 \%$ of patients diagnosed with Hodgkin's disease $24 \mathrm{~h}$ after administration of L-tryptophan. However, a similar increase in KYNA excretion was observed in only 1 of 18 patients with lymphosarcoma enrolled to the study [52].

One of the recent studies carried by Gkotsos et al. revealed some changes in KYNA concentration in urine in the group of patients diagnosed with prostate cancer, but the authors finally concluded that KYNA cannot be considered a reliable marker for monitoring the progress of the disease [53]. The median of KYNA concentration was decreased in samples obtained from patients with prostate cancer in comparison to control group by $28 \%$, however, these differences are not statistically significant. Moreover, there was no correlation between KYNA concentration in urine and the cancer Gleason grade and the age of patients [53]. On the other hand, measurements of KYNA concentration in urine may improve detection of prostate cancer in patients undergoing prostatic massage procedure. KYNA concentration in urine was higher before prostatic massage (Table 1) [53].

Studies on the content of KYNA in the human colon revealed a considerably higher KYNA concentration in mucus samples aspirated from the human caecum or colon ascendens from patients diagnosed with colon carcinoma, Adenoma tubulovillosum or Adenoma tubulare than in a healthy control group (Table 1) [24]. In this regard, KYNA concentration in mucus obtained from patients with a benign polypoid lesion Polipus hyperplasticus did not differ significantly from the control level [24].

Summarizing previously published results indicating the presence of KYNA in cancer tissues and body fluids of subjects with cancer, and differences of KYNA concentration between cancer patients and healthy control group, some of the critical points are worth to be mentioned. The level of KYNA in the tissues and body fluids depends on its endogenous production, supply and elimination from the body (Fig. 2). Therefore, KYNA concentration in serum and urine might not exclusively reflect the ongoing cancer process in the body. KYNA is produced endogenously by normal and cancer cells [24, 40, 41, 54, 55], however, exogenous sources of this compound should not be ignored. KYNA is present in several beverages and products of daily diet. Importantly,

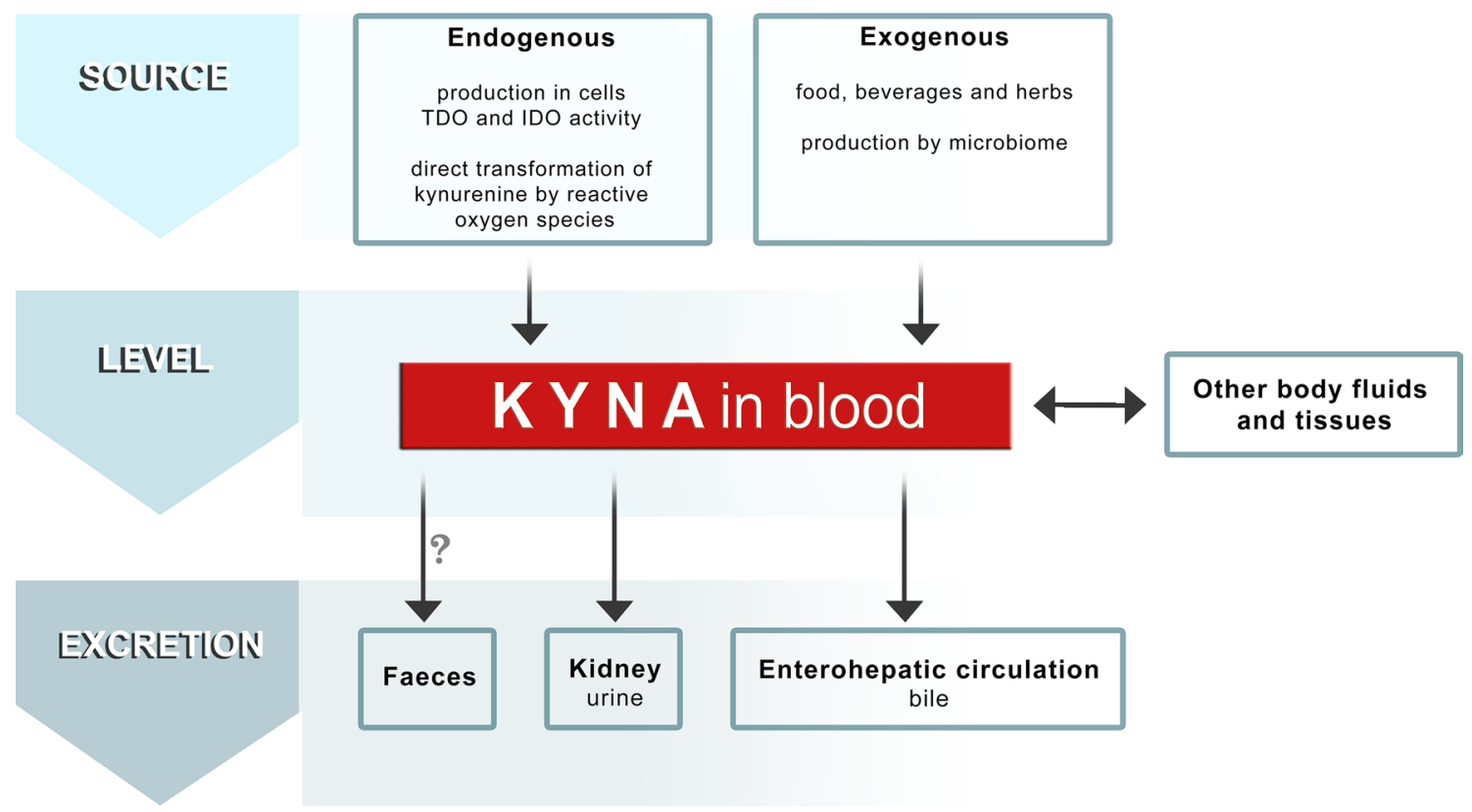

Fig. 2 The fate of KYNA in the body-a schematic representation of factors affecting its level. The level of KYNA in the tissues and body fluids depends on its endogenous production, supply and elimination from the body. KYNA is endogenously produced in cells and as a result of indoleamine 2,3-dioxygenase (IDO) and tryptophan 2,3-dioxygenase (TDO) activity [2, 3, 24] or by direct transformation of kynurenine to KYNA by reactive oxygen species [126]. KYNA is also delivered to the body with food, beverages and herbs [25, 57, 118]. Importantly, intestinal microflora may participate in the forma- tion of the overall amount of KYNA in gastrointestinal tract [23]. KYNA concentration in serum may be also dependent on the efficiency of KYNA excretion from the body with urine. However, it was suggested that KYNA may be excreted with bile as a consequence of the enterohepatic circulation [22]. Our unpublished data showed that KYNA is present in faeces, but its origin (undigested food, intestinal microflora or the way of KYNA excretion from the body) has not been elucidated. Question mark (?) means that there is no direct evidence that KYNA found in faeces comes from blood 
KYNA may be absorbed from the gastrointestinal tract and transported with blood stream to peripheral organs [25, $56,57]$. Moreover, previous studies revealed that intestinal microflora may participate in the formation of the overall amount of KYNA in gastrointestinal tract [23]. In turn, KYNA itself may affect bacterial growth and thus, the biodiversity composition of microbiome [58, 59]. Unfortunately, none of the above-mentioned studies concerning KYNA concentration in serum and other body fluids considers the potential effect of exogenous sources of KYNA on the final results. On the other hand, KYNA concentration in serum may be also dependent on the efficiency of KYNA excretion from the body. In fact, previous studies revealed increased KYNA concentration in serum of patients with renal failure $[60,61]$. Since it was suggested that KYNA may be excreted with bile as a consequence of the enterohepatic circulation [22] it can be speculatively suggested that disruption of this secretion-absorption cycle may significantly influence the KYNA content. Thus, it seems to be reasonable to postulate that pharmacokinetics of KYNA should be carefully considered in further studies devoted to determine cause and effect relationships between KYNA content and cancer promotion and progression.

Taking into consideration the potential influence of endogenous and exogenous sources of KYNA and the process of its excretion on the overall KYNA level in physiological fluids, measurements of this compound in cancer tissue and its surrounding seem to be the most relevant. The majority of studies revealed the elevated KYNA level in tumours in comparison to healthy tissue [36, 39]. However, decreased concentration of KYNA in RCC might be associated with loss of filtration properties by cancer tissue [38]. Importantly, the possible relationship between KYNA content and type of biopsy specimen has not been investigated so far. The critical differences in KYNA content in necrotic core of solid tumours and highly proliferating surface layers cannot be excluded.

\section{KYNA production in cancer cells in vitro}

In vitro experiments confirmed that KYNA is produced by both normal and cancer cells (Table 2). Taking into consideration the significant role of KYNA in the central nervous system, it is not surprising that the first in vitro studies on KYNA production in cancer cells were conducted with glioma. Vezzani et al. [54] reported de novo synthesis of KYNA in slices of human gliomas obtained from biopsy material. Importantly, astrocytomas produced considerably more KYNA than glioblastomas. Similarly, the efficient synthesis of KYNA was confirmed in rat glioma C6 cells [55]. Moreover, Adams et al. [40] revealed that the expression of kynurenine aminotransferase I (KAT I), one of the key enzymes in KYNA synthesis, was significantly decreased after stimulation with interferon-gamma (IFN$\gamma$ ) in human glioma cells, which significantly lowered the KYNA/KYN neuroprotective ratio.

Zdzisińska et al. [41] reported KYNA production in the bone marrow stromal cells (BMSCs) of control and MM patients and by two myeloma cell lines (U266, RPMI8226). However, no significant differences in KYNA production in BMSCs of healthy control subjects and MM patients were observed. Moreover, KAT I and KAT II were expressed in BMSCs of healthy control subjects, as well as in BMSCs of patients diagnosed with MM and MGUS. Interestingly, despite the physiological similarity between examined myeloma cell lines, their ability to produce KYNA differed significantly. KYNA production in U266 cells was almost fivefold higher than in RPMI8226 cells [41].

Interesting results were obtained from the studies on KYNA production in colon epithelial and cancer cells. KYNA synthesis in colon adenocarcinoma cell lines Caco2, HT-29 and LS-180 was considerably higher in comparison to normal colon epithelial cells [24].

Table 2 KYNA production in cancer cells in vitro

\begin{tabular}{|c|c|c|c|c|}
\hline Cell type & Cell line & KYNA production & Comments & References \\
\hline Human gliomas & Biopsy material & $\begin{array}{l}43.7 \pm 12.2 \mathrm{pmol} \mathrm{KYNA} / \mathrm{mg} \text { protein } / 2 \mathrm{~h} \\
10.4 \pm 2.5 \mathrm{pmol} \mathrm{KYNA} / \mathrm{mg} \text { protein } / 2 \mathrm{~h}\end{array}$ & $\begin{array}{l}\text { Astrocytoma (incubation with } 200 \mu \mathrm{M} \text { L-KYN, } 2 \text { h) } \\
\text { Glioblastoma (incubation with } 200 \mu \mathrm{M} \text { L-KYN, } 2 \text { h) }\end{array}$ & {$[54]$} \\
\hline Rat glioma & C6 & $29.7 \mathrm{pmol} \mathrm{KYNA} / \mathrm{mg}$ protein/2 h & Incubation with $5 \mu \mathrm{M}$ L-KYN, $5 \mathrm{~h}$ & {$[55]$} \\
\hline Human myeloma & $\begin{array}{l}\text { U266 } \\
\text { RPMI8226 }\end{array}$ & $\begin{array}{l}\sim 7 \mathrm{pmol} \mathrm{KYNA} / 5 \times 10^{5} \text { cells } / 2 \mathrm{~h} \\
\sim 1.5 \mathrm{pmol} \mathrm{KYNA} / 5 \times 10^{5} \text { cells } / 2 \mathrm{~h}\end{array}$ & Incubation with $5 \mu \mathrm{M}_{\mathrm{L}}-\mathrm{KYN}, 2 \mathrm{~h}^{\mathrm{a}}$ & [41] \\
\hline $\begin{array}{l}\text { Human colon } \\
\text { adenocarci- } \\
\text { noma }\end{array}$ & $\begin{array}{l}\text { Caco-2 } \\
\text { HT-29 } \\
\text { LS-180 }\end{array}$ & $\begin{array}{l}4.21 \mathrm{pmol} / 1 \times 10^{5} \text { cells } / 2 \mathrm{~h} \\
1.39 \mathrm{pmol} / 1 \times 10^{5} \text { cells } / 2 \mathrm{~h} \\
1.18 \mathrm{pmol} / 1 \times 10^{5} \text { cells } / 2 \mathrm{~h}\end{array}$ & Incubation with $5 \mu \mathrm{M}$ L-KYN, $2 \mathrm{~h}$ & {$[24]$} \\
\hline
\end{tabular}

${ }^{\mathrm{a}}$ Estimated from graphs 


\section{Effect of KYNA on cancer cell proliferation in vitro}

Taking into consideration KYNA production by cancer cells, the principal question is whether it may play any role in the process of carcinogenesis or cancer progression. There are only a few studies concerning the effect of KYNA on cancer cells' proliferation, thus, this matter has not been fully elucidated (Table 3). Di Serio et al. [62] reported a major stimulatory effect on the proliferation rate of mouse microglia N11 $\left(\mathrm{ED}_{50}=25 \mathrm{nM}\right)$ and human glioblastoma U-343 MG cells. This effect was not observed in the mouse (J774) and human (U937) macrophage cell lines. Importantly, the mentioned study was conducted with the use of reduced serum culture medium (supplemented with 3\% serum) [62], and the stimulatory effect of KYNA on cancer cell proliferation has not been confirmed under normal experimental conditions (10\% serum) in other types of cancer cells [24, 37, 38, 63]. It should be noted that serum deprivation itself inhibited proliferation of U-343 MG cells in comparison to standard conditions and importantly, KYNA did not fully reverse this effect [62]. However, it cannot be excluded that KYNA interacts with different elements of signalling pathways or cell cycle regulators under stress conditions. Interestingly, cultured human glioma cells exposed to INF- $\gamma$ presented significantly lower expression of KAT I [40]. It cannot be excluded that immune system may play an important role in biological response of cancer cells exposed to KYNA.

On the contrary, recent studies revealed an inhibitory effect of KYNA on the proliferation of human glioblastoma T98G cells $\left(\mathrm{IC}_{50}=1.3 \mathrm{mM}\right)$ [37]. It also significantly inhibited the proliferation of human colon and renal cancer cells $[24,38]$. KYNA exerted an antiproliferative activity against colon adenocarcinoma HT-29, LS-180 and Caco-2 cells with $\mathrm{IC}_{50}$ of $0.9,0.2$ and $1.2 \mathrm{mM}$, respectively [24]. Importantly, it should be indicated that, a clear-cut dose-dependent inhibitory effect was observed in concentrations above $0.01 \mathrm{mM}$ for HT-29 cells [24]. In vitro studies demonstrated antiproliferative properties of KYNA also against RCC Caki- 2 cells $\left(\mathrm{IC}_{50}=0.04 \mathrm{mM}\right)[38]$.

Importantly, KYNA inhibited other cellular processes in cancer cells. KYNA in millimolar concentrations significantly decreased DNA synthesis in T98G $\left(\mathrm{IC}_{50}=8.9 \mathrm{mM}\right)$ [37], HT-29 $\left(\mathrm{IC}_{50}=4.4 \mathrm{mM}\right)$ [63] and Caki-2 $\left(\mathrm{IC}_{50}=2.1 \mathrm{mM}\right)$ [38] cells. It also inhibited the migration of glioblastoma $\left(\mathrm{IC}_{50}=0.6 \mathrm{mM}\right)$ [37] and RCC [38] cells. Although the exact molecular mechanism of the action of KYNA on cancer cells' proliferation and motility has not been revealed, its possible interactions with receptors and several proteins involved in signal transmission and cell cycle regulation suggest the potential function of KYNA in the process of carcinogenesis (Fig. 3).

\section{Effect of KYNA on receptors and intracellular processes in cancer cells}

\section{Receptors}

Despite the fact that KYNA was initially found to block all ionotropic glutamate receptors [64], later studies indicated its higher potency as a competitive antagonist of the strychnine-insensitive glycine co-agonist site of the $\mathrm{N}$-methylD-aspartate (NMDA) receptor [65] and as a non-competitive inhibitor of the $\alpha-7$ nicotinic acetylcholine receptor (alpha7 nAChR) [66]. Moreover, KYNA is an agonist of

Table 3 Effect of KYNA on proliferation, DNA synthesis and migration of cancer cells in vitro

\begin{tabular}{|c|c|c|c|c|c|}
\hline $\begin{array}{l}\text { Cellular process/detection } \\
\text { method }\end{array}$ & Cell type & Cell line & Effect & Comments & References \\
\hline \multirow[t]{6}{*}{ Proliferation } & Human glioblastoma & U-343 MG & Increase in growth rate & $\begin{array}{l}\text { KYNA } 1 \mu \mathrm{M} \text { and } 10 \mu \mathrm{M} \text {; } \\
\text { medium containing low } \\
\text { serum }(3 \%)\end{array}$ & {$[62]$} \\
\hline & Human glioblastoma & T98G & Antiproliferative effect & $\mathrm{IC}_{50}=1.3 \mathrm{mM}$ & {$[37]$} \\
\hline & \multirow{3}{*}{$\begin{array}{l}\text { Human colon adenocarci- } \\
\text { noma }\end{array}$} & Caco-2 & & $\mathrm{IC}_{50}=1.2 \mathrm{mM}$ & \multirow[t]{3}{*}[24]{} \\
\hline & & HT-29 & & $\mathrm{IC}_{50}=0.9 \mathrm{mM}$ & \\
\hline & & LS-180 & & $\mathrm{IC}_{50}=0.2 \mathrm{mM}$ & \\
\hline & Human renal cell carcinoma & Caki-2 & & $\mathrm{IC}_{50}=0.04 \mathrm{mM}$ & {$[38]$} \\
\hline \multirow[t]{3}{*}{ DNA synthesis (BrdU) } & Human glioblastoma & T98G & \multirow[t]{3}{*}{ Decreased DNA synthesis } & $\mathrm{IC}_{50}=8.9 \mathrm{mM}$ & {$[37]$} \\
\hline & $\begin{array}{l}\text { Human colon adenocarci- } \\
\text { noma }\end{array}$ & HT-29 & & $\mathrm{IC}_{50}=4.4 \mathrm{mM}$ & {$[63]$} \\
\hline & Human renal cell carcinoma & Caki-2 & & $\mathrm{IC}_{50}=2.13 \mathrm{mM}$ & {$[38]$} \\
\hline \multirow[t]{2}{*}{ Migration (wound assay) } & Human glioblastoma & T98G & \multirow[t]{2}{*}{ Inhibition of migration } & $\mathrm{IC}_{50}=0.6 \mathrm{mM}$ & {$[37]$} \\
\hline & Human renal cell carcinoma & Caki-2 & & $\begin{array}{l}47 \% \text { in comparison to con- } \\
\text { trol after } 24 \mathrm{~h} \text { of incuba- } \\
\text { tion with KYNA } 2.5 \mathrm{mM}\end{array}$ & {$[38]$} \\
\hline
\end{tabular}




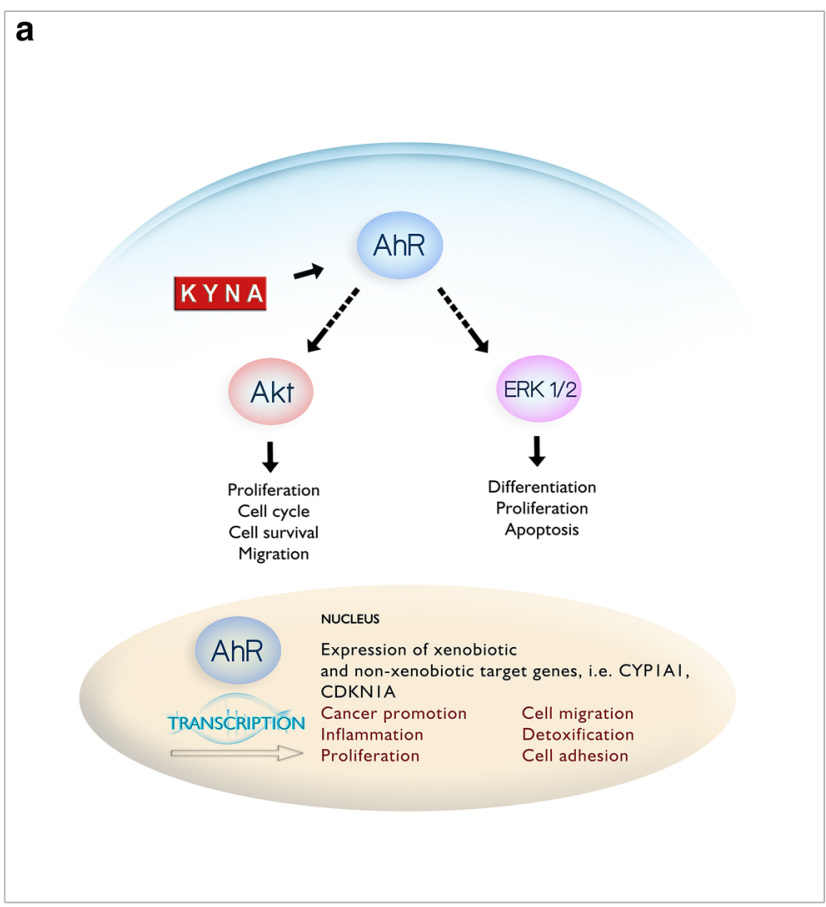

Fig. 3 A schematic presentation of selected cellular processes influenced by KYNA. KYNA inhibits phosphorylation of protein kinase B (Akt), extracellular signal-regulated kinase (ERK 1/2), and p38 mitogen-activated protein kinase (p38) [99]. The effect of KYNA on phosphoinositide 3-kinase/protein kinase B PI3K/Akt pathway may lead to disruption of various cellular processes including proliferation, cell cycle, cell survival and migration. Interaction between KYNA and ERK pathway may affect the processes of differentiation, proliferation or apoptosis, whereas interaction between KYNA and p38 pathway may affect the processes of proliferation, cell motility, apoptosis, stress response and inflammation. Moreover, KYNA enhances the protein expression of $\beta$-catenin which is involved in adhesion, development, cell survival and proliferation. The potential relationship between AhR (a) and GPR35 (b) receptors and mentioned signalling pathways is presented; however, the specific mechanism of

G-protein coupled receptor (GPR35), which is predominantly expressed in immune and gastrointestinal tissues [67], and an agonist of aryl hydrocarbon receptor (AhR) [68, 69]. Thus, KYNA may exert various biological effects on cancer cells by interaction with specific receptors (Table 4).

Although the molecular mechanism of antiproliferative activity of KYNA is not fully elucidated, an involvement of glutamate receptors should be considered. Previous studies indicated that glutamate antagonists inhibit proliferation and increased cell death of several cancer cell lines expressing this type of receptors on their surface, including HT-29 cells [70, 71]. Moreover, KYNA reversed the stimulatory effect of glutamate on glioma $\mathrm{T} 98 \mathrm{G}$ cell proliferation, and enhanced the antiproliferative effect of glutamate receptor antagonists MK801 and GYKI 52466 [37].

The anticancer potential of KYNA may be also determined by interaction with alpha7 $\mathrm{nAChR}$ which is
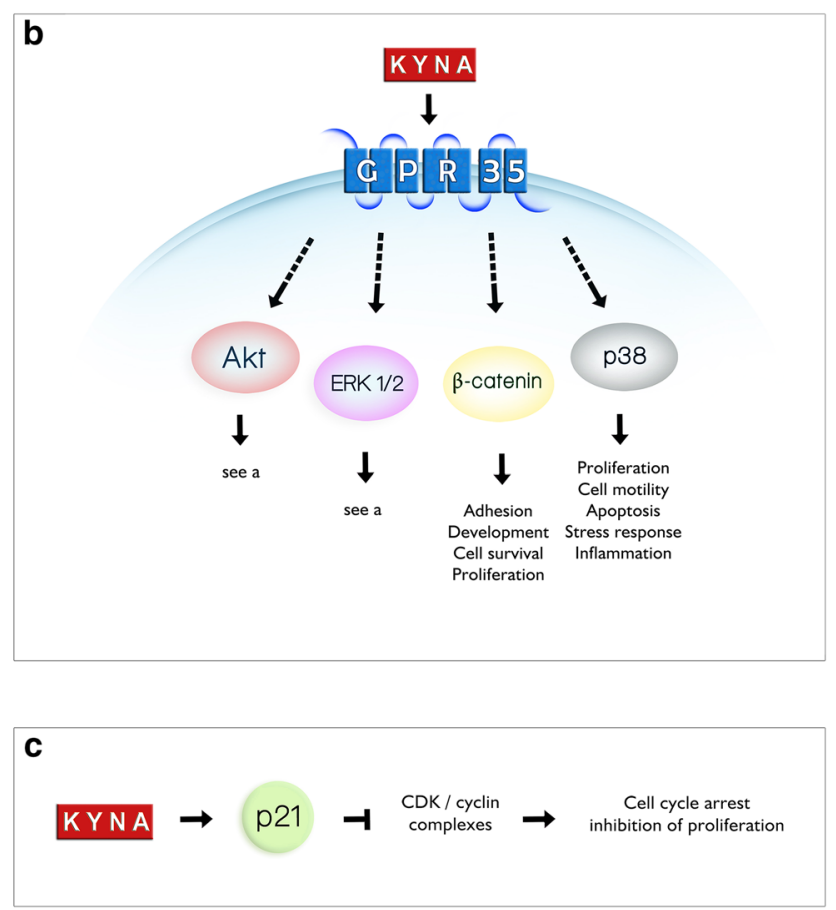

KYNA interactions has not been fully elucidated. a KYNA is an agonist of the aryl hydrocarbon receptor AhR. According to the biological effects of AhR activation, three possible types of interactions may be suggested: via PI3K/Akt pathway, ERK signalling pathway or by activation of the expression of xenobiotic and non-xenobiotic target genes (based on [127-129]). b KYNA activates G-protein-coupled receptor 35 (GPR35) which may lead to inhibition of phosphorylation of various signalling proteins, including Akt, ERK, and p38 mitogenactivated protein kinase (p38). Additionally, activation of GPR35 may lead to increase in $\beta$-catenin expression (based on $[59,130]$ ). $\mathbf{c}$ KYNA enhances the protein expression of cyclin-dependent kinase (CDK) inhibitor $\mathrm{p} 21^{\text {Waf } 1 / \text { Cip } 1}$ resulting in possible inhibition of cyclin D/CDK4/CDK6, cyclin E/CDK2, cyclin A/CDK2 and cyclin B/ CDK1 complexes which may lead to cell cycle arrest and antiproliferative activity [63]

expressed in neuronal and various non-neuronal cells including endothelial and smooth muscle cells [72]. alpha7 nAChR is strongly associated with pro-angiogenic and pro-proliferative activity of nicotine, mediated by ERK signalling pathway [73]. Tu et al. [74] also reported the critical role of this receptor in progression and metastasis of gastric cancer. Thus, it cannot be excluded that antiproliferative activity of KYNA on various cancer cells is mediated, even partially, by the inhibition of alpha7 $\mathrm{nAChR}$. Although the antiangiogenic potential of KYNA, as an antagonist of alpha7 nAChR, in cancer cells has not been excessively studied, Arias et al. [73] reviewed that selective (alpha-bungarotoxin and methyllycaconitine) and non-specific (mecamylamine) antagonists of this receptors inhibited proliferation of endothelial cells and angiogenesis. Importantly, alpha7 nAChR is also involved in the modulation of anti-inflammatory response [75], 


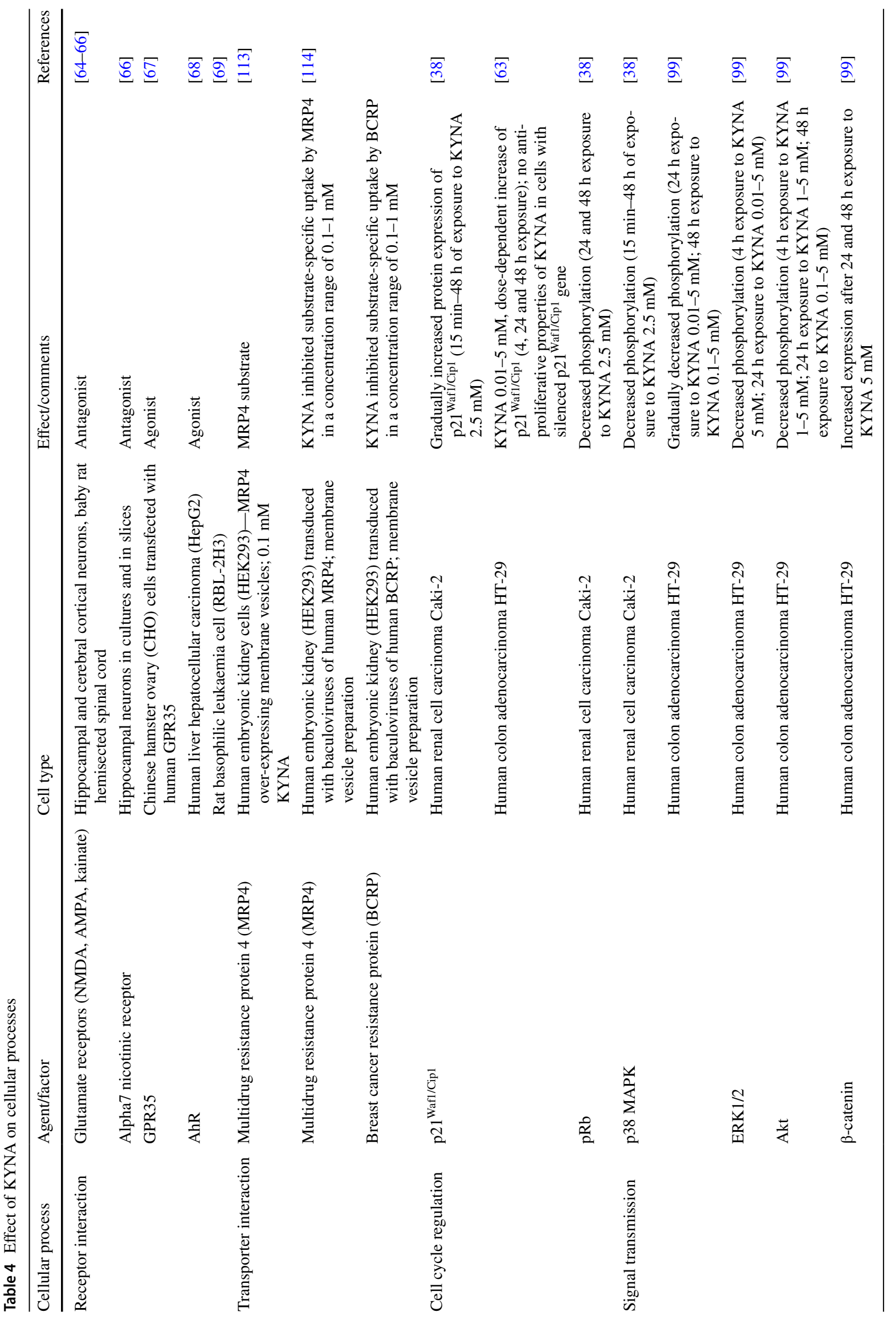


thus, it is regarded as an attractive target for anticancer therapy.

On the other hand, KYNA is an endogenous agonist of AhR which is involved in several processes including cell proliferation, apoptosis, adipose differentiation, tumour suppression and immune cell differentiation (reviewed in [76]) (Fig. 3a). KYNA in nanomolar concentrations is an efficient agonist for the human AhR inducing xenobiotic metabolism in cells and production of interleukin-6 (IL6), an important mediator of pro-tumorigenic properties [68]. DiNatale et al. [68] revealed that KYNA induces mRNA expression of CYPIAI and CYPIA-mediated metabolism in vitro.

The potential role of AhR and its ligands in the process of carcinogenesis has been previously reviewed [77]. It was reported that $\mathrm{AhR}$ is overexpressed in some cancers including lung carcinoma, gastric carcinoma and medulloblastoma [78] and an oncogenic potential of AhR was reported in hepatocarcinoma and stomach tumour [79]. Most of the data point to a direct and indirect interaction between the AhR receptor and tumour promotion, progression and the phenomenon of immune escape in tumours [80]. Importantly, previous studies suggested the indirect role of AhR signalling in cancer promotion, progression and metastasis by affecting kynurenine pathway and immune response. The expression of some enzymes of kynurenine pathway, IDO1 and TDO2, is strictly controlled by AhR. Activity of IDO1 and TDO2, decreasing the availability of tryptophan in the tumour environment, may lead to suppression of immune response via inhibition of antigen-specific T-cell response and promotion of tolerogenic phenotype in dendritic cells [81, 82]. Thus, potential pro-carcinogenic effect of KYNA as AhR ligand cannot be excluded. However, activation of AhR may also lead to inhibition of the proliferation of various cancer cells, including liver, prostate and breast cancer and intestinal carcinogenesis in mice [83-86]. It was hypothesized that this apparently mutually exclusive function of $\mathrm{AhR}$ in tumour progression may be partially dependent on the specific role of various cell types in the process of migration [87]. Although KYNA is considered as an agonist [68], in some cases, its biological impact on cellular processes is similar to the biological activity of AhR antagonist, such as resveratrol [69]. Mutz et al. [88] reported that EWS-FLI1 fusion protein, involved in progression of an aggressive paediatric tumour Ewing sarcoma (ES), suppresses autocrine AhR signalling by interaction with kynurenine pathway. It should be noted that KYNA may also affect immune response via AhR, since this receptor has an important regulatory role in inflammation and its activation prevents proinflammatory cytokine induction in cells exposed to an inflammatory stimulus [89-92].

Despite the fact, that GPR35 agonists have not been directly related to pro- or antiproliferative activity towards cancer cells to date, GPR35 signalling via ERK kinase is involved in several processes including proliferation, cell survival and metastasis [93] (Fig. 3b). Thus, the interaction between KYNA and GPR35 in cancer cannot be excluded. It should be noted that KYNA as an agonist may also modulate the immune response to the initiation and progression of carcinogenesis via direct interaction with GPR35, which is predominantly expressed on immune cells [67]. However, the role exerted by KYNA on the defensive reaction in cancer via GPR35 receptors located on immune cells [67] is as yet unknown. Activation of GPR35 by KYNA induces the internalization of the receptor and leads to calcium mobilisation and production of inositol phosphate $\left(\mathrm{IP}_{3}\right)$ [67].

The direct interaction of KYNA with receptor seems to be a critical step determining biological activity of the substance. However, the involvement of human organic anion transporters 1 (hOAT1) and 3 (hOAT3) in the uptake of KYNA has been also suggested [94]. The mentioned transporters are mainly expressed in the brain and the kidney. Similarly, mining the TCGA [95] and GTEx [96] datasets revealed no or very low expression of genes coding hOAT1 (SLC22A6) and hOAT3 (SLC22A8) in most cancer types except for brain and renal tumours (data not shown). Importantly, hOAT 1 and hOAT3 expression was markedly decreased in renal cancer tissue in comparison to healthy renal tissue. On the other hand, KYNA concentration might be also increased in the cells due to its intracellular synthesis from kynurenine which is taken up by $\mathrm{Na}^{+}$-independent transporter of neutral amino acids as shown by Speciale et al. [97] in astrocytes.

\section{Signalling pathways}

Importantly, KYNA has a modulatory effect on signalling pathways which are well-known targets of GPR signalling, including the phosphoinositide 3-kinase (PI3K)/protein kinase B (Akt) and mitogen-activated protein kinase (MAPK) pathways [98, 99]. KYNA was shown as a potent inhibitor of extracellular signal-regulated kinases (ERK) 1/2, p38 MAPK, and Akt [99] (Fig. 3). These signalling pathways are directly involved in processes of proliferation, survival, apoptosis and migration [100]. The effect of KYNA on signalling pathways in cancer cells was probed in colon adenocarcinoma [63, 99] and renal cancer cells [38]. Importantly, KYNA in high concentrations exerted an inhibitory effect on signalling pathways in cancer cells, which is consistent with the concentration range at which KYNA inhibits tumour cell proliferation. KYNA in millimolar concentrations decreased phosphorylation of ERK 1/2 in a dose-dependent manner in HT-29 adenocarcinoma cells [99]. It might be suggested that p38 kinase is more sensitive to the inhibitory effect of KYNA, as inhibition of $\mathrm{p} 38$ phosphorylation was observed at 10 times lower concentration of KYNA [99]. Importantly, 
a similar effect of p38 inhibition was observed in renal cell carcinoma Caki-2 cells [38]. Moreover, KYNA in a dosedependent manner inhibited phosphorylation of Akt in colon adenocarcinoma HT-29 cells, the main element of PI3K/Akt pathway whose disturbance may lead to cancer promotion and progression [99].

On the other hand, KYNA interaction with GPR35 and mentioned signalling pathways may also affect immunological response to cancer cells. It was suggested that KYNA-GPR35 interaction might lead to suppression or limitation of inflammation [59]. Moreover, KYNA leads to $\beta$-catenin accumulation in colon cancer cells which may also be dependent on interaction with $\operatorname{GPR}[99,101]$ (Fig. 3). Interestingly, $\beta$-catenin (WNT) signalling pathway is involved in inhibition of inflammation via NF- $\kappa B$ pathway $[59,102]$. All of these data suggested potential double-edged role of KYNA in carcinogenesis. Taking into consideration an anti-inflammatory potential of KYNA, this compound may be considered as a potent anticancer agent since continuous inflammation is one of the factors which may induce process of carcinogenesis [103, 104]. On the other hand, the proper immune response may inhibit the early stages of carcinogenesis or prevent spreading of cancer cells into the whole body $[105,106]$.

\section{Cell cycle regulators}

Moreover, recent studies revealed that KYNA affected cell cycle regulators and downstream elements of signalling pathways, which lead to antiproliferative activity towards cancer cells (Table 4). One of the affected proteins is cyclindependent kinase inhibitor p21 Waf1/Cip1 (Fig. 3c). KYNA in colon cancer HT-29 and renal cancer Caki-2 cells significantly enhanced expression of $\mathrm{p} 21^{\text {Waf1/Cip } 1}$, which is involved in cell cycle regulation, apoptosis and cell differentiation [38, 63, 107, 108]. Inhibition of phosphorylation of $\mathrm{Rb}$ in Caki-2 cells exposed to KYNA was also reported [38]. Importantly, this protein controls progression through the restriction point within the G1 phase of the cell cycle, and thus, regulates cell growth and proliferation. KYNA affects also signalling kinases inhibiting p38 MAPK in Caki-2 cells, which is involved in the control of cell cycle in G1/S and G2/M checkpoints through regulation of various genes coding cytokines, transcriptional factors and receptors [38, 109, 110].

\section{KYNA and cancer therapy: future perspectives and potential risks}

Summarizing all data, the question arises whether KYNA may have some clinical significance. Although there are limited data, the future use of KYNA as an anticancer agent or as a supportive agent in standard cancer therapy cannot be excluded. Undoubtedly, KYNA in millimolar concentrations exerted antiproliferative activity towards several cancer cell lines [24, 37, 38], and its local concentration may be easily increased. Previous studies indicated that it is absorbed from the intestine into the blood stream and reaches high concentrations in the liver and kidney [25]. Moreover, it was reported that the intravenous administration of KYNA in a dose as high as $100 \mathrm{mg} / \mathrm{kg} / \mathrm{h}$ in rats is well tolerated [111]. A similar effect was observed after long-term application of KYNA in the drinking water [112]. It is also worth mentioning the possible interaction of KYNA with cytostatic drug used in standard chemotherapy. A recent study revealed that KYNA enhanced the antiproliferative effect of temozolomide, a drug used in glioblastoma therapy [37]. Although the molecular mechanism of this phenomenon has not been elucidated, the involvement of glutamate receptors may be suggested. Rzeski et al. [71] showed that glutamate antagonists enhanced the antiproliferative effect of cytostatic drugs, including cyclophosphamide and thiotepa in rhabdomyosarcoma and neuroblastoma cells. However, the other mechanism should be also considered. Previous studies revealed that KYNA inhibited substrate-specific uptake by two important efflux pumps-multidrug resistance protein 4 (MRP4) [113] and breast cancer resistance protein (BCRP) [114], expressed in a broad spectrum of tissues including stem cells, placenta, liver, small intestine, colon, lung, kidney [115]. Despite their important physiological functions in the detoxification of xenobiotics, they are also involved in drug resistance in cancer. KYNA as an inhibitor may prevent this phenomenon, thereby enhancing the effectiveness of standard cytostatic drugs used in cancer therapy. Numerous results consistently indicate that KYNA in high concentrations inhibits viability, proliferation and migration of many cancer cell lines in vitro [24, 37, 38, 63]. Compatible with these findings are reports on the action of KYNA on cell cycle regulators and signalling pathways involved in cell proliferation [38, 63, 99]. Furthermore, recent studies revealed that KYNA inhibits MRP4 [113] and BCRP [114] transporters which are responsible for drug resistance in cancer. Interestingly, it was found that KYNA potentiates effectiveness of the cytostatic drug [37] used in the therapy of cancer. Thus, the use of KYNA as an adjunctive treatment in cancer medication and/or dietary supplementation in cancer prevention cannot be excluded.

Given our current state of knowledge, types of cancers with the genetic vulnerabilities to KYNA cannot be clearly identified. However, the expression of specific receptors, including AhR, GPR35 and glutamate receptors, in cancer cells increases the probability of KYNA interaction. Interestingly, the expression of GPR35 differs in various cancer types in comparison to normal tissue. All cancer types can be divided into three groups: cancers with decreased expression 
of GPR35 (i.e., thyroid, prostate and testicular cancer), cancers with GPR35 overexpression (i.e., pancreatic, stomach and colon cancer) and cancers with constant expression of GPR35 (i.e., ovarian and breast cancer) (Fig. 4a), which may be a suggestion for future therapeutic treatment.

Taking into consideration the KYNA-mediated increase of $\mathrm{p} 21^{\text {Waf } 1 / \text { Cip } 1}$ protein expression in colon adenocarcinoma cells [63], the other group of tumours probably susceptible to KYNA are tumours with decreased expression of this cell cycle regulator, including ovarian serous cystadenocarcinoma and testicular germ cell tumours (Fig. 5). Importantly, cancers with decreased expression of CDKN1A have also decreased expression of genes coding KATs, enzymes directly involved in KYNA synthesis (Fig. 5). Similarly, in pancreatic adenocarcinoma and lymphoid neoplasm diffuse

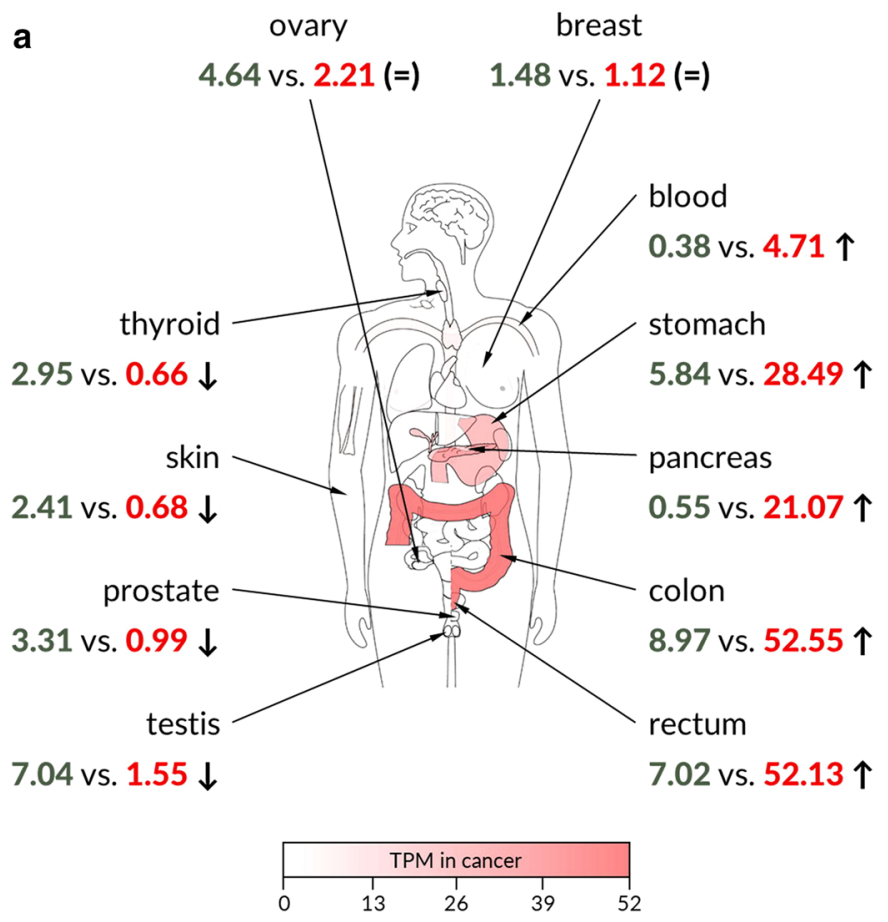

large B-cell lymphoma cells, representing cancers with CDKN1A overexpression, the KATs expression is significantly elevated (Fig. 5).

On the other hand, the conclusion that KYNA might promote carcinogenesis may be of great importance. Mutations in genes coding enzymes of the kynurenine pathway in tumour tissue are relatively rare in comparison to the frequency of mutations in TP53, PIK3CA, PTEN, KRAS and $B R A F$ genes (Fig. 4b). However, in most cases KYNA concentration was increased in cancer tissue and biological fluids in comparison to control [24, 36, 39, 41, 45], suggesting that lowering KYNA level may somehow improve the clinical outcome of cancer patients. However, KYNA deficiency status has not been revealed so far, due to its endogenous production by cells as well as continuous supply with

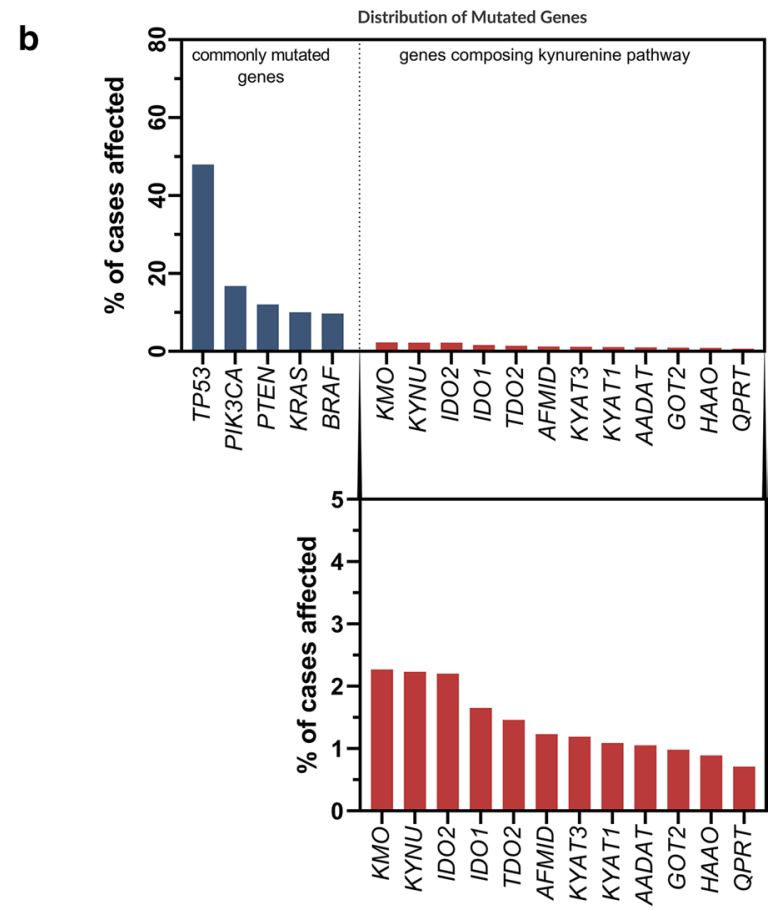

Fig. 4 Data mining on GPR35 gene expression and on mutation frequency of genes composing kynurenine pathway. a GPR35 gene expression profiles across normal tissues and paired tumours and were generated using GEPIA2 [131] based on TCGA [95] and GTEx [96] datasets. Retrieved expression values are provided in transcripts per million (TPM) as normal (green) vs. cancer (red) for every listed tissue. Four types of tumours were identified to display significant downregulation of GPR35 (left side of the panel; marked by $\downarrow$ ). Five different types of tumours showed significant upregulation of GPR35 in comparison to respective normal tissues (right side of the panel; marked by $\uparrow$ ). No significant changes in GPR35 expression in other types of tumours were identified. Two examples of such tumours are given on the top of the panel $(=)$. Statistical analysis: ANOVA $(q$ value cutoff $=0.01 ; \log _{2} \mathrm{FCl}$ cutoff $\left.=1\right)$. Red colour intensity on different parts of the depicted human anatomical outline represents the expression level of GPR35 in human cancers. TPM, transcripts per million; $\uparrow$, upregulation of GPR35 in cancer vs. normal; $\downarrow$, downregulation of GPR35 in cancer vs. normal; $(=)$, no significant changes in GPR35 expression. b Data on the frequency of mutations in genes involved in tryptophan catabolism on the kynurenine pathway were extracted from TCGA [95] database through Genomic Data Commons Data Portal available at https://portal.gdc.cancer.gov. A set of five genes commonly mutated in human cancers were provided for comparison. TP53 tumor protein p53, PIK3CA phosphatidylinositol-4,5-bisphosphate 3-kinase catalytic subunit alpha, PTEN phosphatase and tensin homolog, KRAS KRAS proto-oncogene, GTPase, $B R A F$ B-Raf proto-oncogene, serine/threonine kinase, $K M O$ kynurenine 3-monooxygenase, $K Y N U$ kynureninase, IDO2 indoleamine 2,3-dioxygenase 2, IDO1 indoleamine 2,3-dioxygenase 1, TDO2 tryptophan 2,3-dioxygenase, AFMID arylformamidase; KYAT3 (KAT III), kynurenine aminotransferase 3, KYAT1 (KAT I) kynurenine aminotransferase 1, AADAT (KAT II) aminoadipate aminotransferase, GOT2 (KATIV), glutamic-oxaloacetic transaminase 2, HAAO 3-hydroxyanthranilate 3,4-dioxygenase, $Q P R T$ quinolinate phosphoribosyltransferase 
Fig. 5 Expression pattern of genes coding kynurenine aminotransferases (KAT I-IV) in human tumours with down- and upregulated CDKN1A (p21 Waf1/ $\left.{ }^{\mathrm{Cip} 1}\right)$. GEPIA2 [131] was queried for tumours displaying significant changes in the expression of CDKN1A, gene encoding for $\mathrm{p} 21^{\mathrm{Waf} 1 / \mathrm{Cip} 1}$ cyclindependent kinase inhibitor. Ovarian serous cystadenocarcinoma and testicular germ cell tumour displayed significant downregulation of $C D K N 1 A$ in comparison to paired normal tissues (a). On the contrary, pancreatic adenocarcinoma and lymphoid neoplasm diffuse large B-cell lymphoma showed significant upregulation of CDKN1A (b). Expression of genes coding for kynurenine aminotransferases, i.e., KYAT1 (KAT I; c, d), AADAT (KAT II; e, f), KYAT3 (KAT III; $\mathbf{g}, \mathbf{h}$ ) and GOT2 (KAT IV; i, j), was examined in the same set of cancers. Significant downregulation of KYAT1 (c) and AADAT (e), but not of $A A D A T(\mathbf{g})$ nor of GOT2 (i), was observed in ovarian serous cystadenocarcinoma and testicular germ cell tumours-tumours displaying CDKN1A (p21 $\left.{ }^{\text {Waf1/Cipl } 1}\right)$ downregulation. CDKN1A (p21 $1^{\text {Waf1/Cip1 }}$ ) upregulation in pancreatic adenocarcinoma was accompanied by an increase in KYAT1 (KAT I; d) and GOT2 (KAT IV; j). Similarly, lymphoid neoplasm diffuse large B-cell lymphoma showed increase in KYATl (KAT I, d), KYAT3 (KAT III; h) and GOT2 (KAT IV; $\mathbf{j})$. Differences in the expression levels were analysed by ANOVA. $* p<0.01$ and fold-change threshold $\left(\log _{2} \mathrm{FCl}\right.$ cutoff) of 1
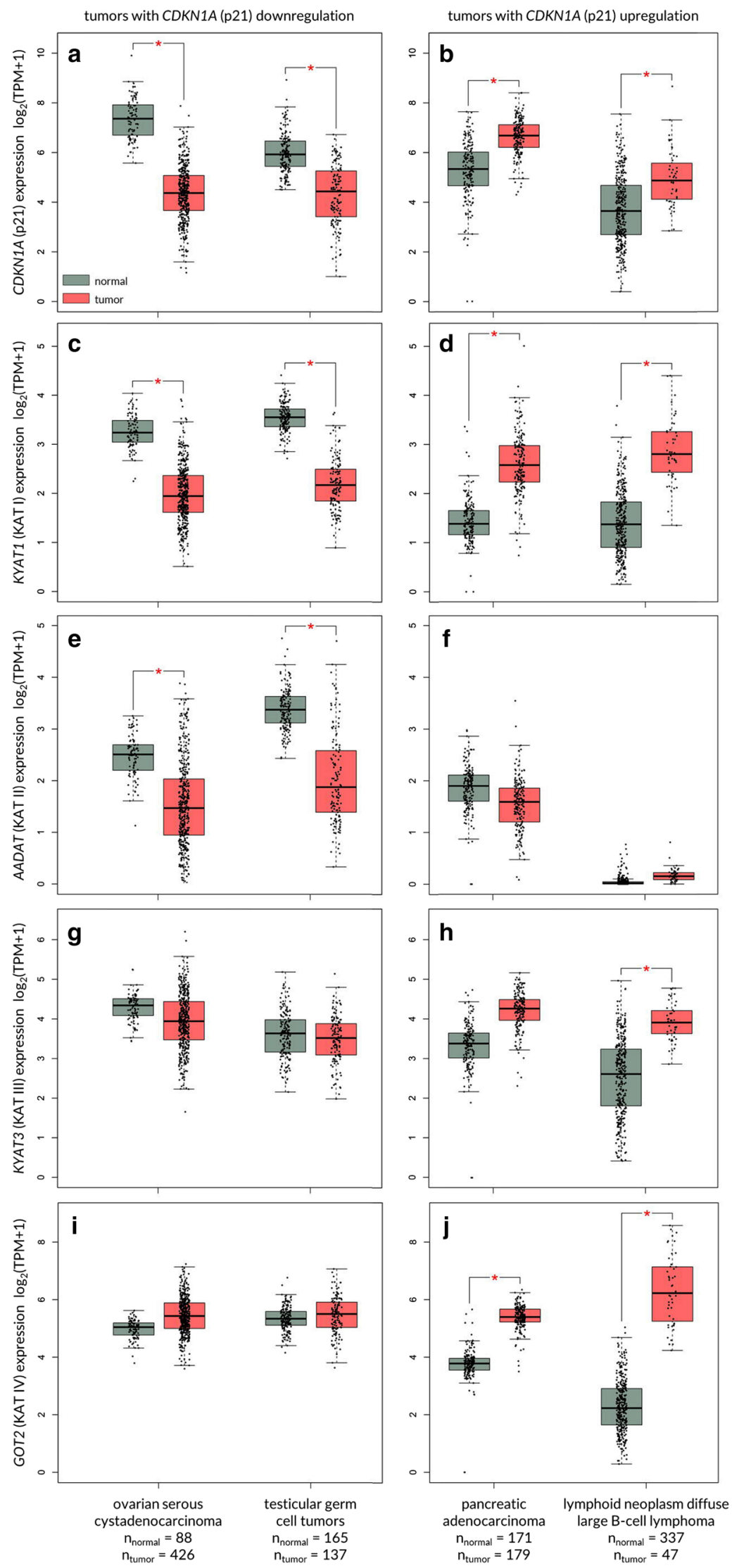
daily diet $[21,25,56,57]$. On the other hand, the current state of knowledge does not allow to state clearly whether increased concentration of KYNA in tumours is the cause or the effect of the carcinogenesis. Some results point to the pro-carcinogenic properties of KYNA, e.g., enhanced proliferation of certain cell lines in the presence of KYNA [62] and the modulatory action of KYNA on AhR receptors [68, 69], which are believed to be involved in several processes, including cell proliferation, apoptosis, differentiation and tumour growth. The molecular mechanism of biological activity of KYNA in cancer cells is not fully elucidated and further studies should be undertaken. Due to limited data, it cannot be excluded that KYNA also affects other elements of signalling pathways or cell cycle regulators, and therefore, under certain conditions, supports cancer cell proliferation, motility or survival. KYNA is not only an endogenous constituent of the human body but it is also a component of our daily food. A high content of KYNA was reported in conventional nourishment, such as, honey, broccoli, cauliflower, and potato [25]. The finding that KYNA is easily absorbed from the digestive system and reaches high concentrations in serum and organs [25] seems to be truly significant. Considering the hypothesis of pro-carcinogenous properties of KYNA, immediate significant changes in our eating habits should be recommended. In addition, numerous food products should be strictly avoided.

\section{KYNA and cancer: directions for future research}

Here, we focused on the potential role of KYNA in the process of carcinogenesis and cancer progression. However, accumulated data concerning a relationship between KYNA and cancer are inconsistent and do not provide enough evidence to reach a final conclusion on the role of KYNA in cancer. To clarify the ambiguous role of KYNA in carcinogenesis and cancer progression, large-scale multicentre studies carried out on different levels, in vitro, in vivo and clinical studies, are necessary. Particularly, the following issues should be elucidated:

\section{Distribution of KYNA in cancer and surrounding tissues}

The research on a large group of cancer patients would be of great scientific value. As it was discussed previously, due to various factors affecting the KYNA level in physiological fluids, measurements of this compound in cancer and surrounding tissues seem to be the most relevant. Importantly, in contrast to previous one, the study concerning changes in KYNA concentration between cancer patients and control group should include additional analyses of patients' diet (low and high KYNA content) and markers of inflammation, which, as it was discussed previously, may influence the KYNA concentration in body fluids.

\section{Expression of genes coding enzymes of kynurenine pathway and KAT distribution in cancer and surrounding tissues}

Searching for correlation between KYNA content, type of cancer and the stage of cancer progression should include not only the changes in the physiological level, but also in the level of genetic alternations. The possible alternations in expression level of genes coding kynurenine pathway enzymes have not been excessively studied in cancer so far.

\section{Cancer progression in animals with KAT overexpression and KAT knockout animals}

Genetic modifications, including knockout animals, animals with KAT or KMO overexpression, may introduce significant changes in KYNA level in particular organs or the entire organism and may result in a better understanding of the role of KYNA in the cancer promotion and progression. Interestingly, due to fast life cycle, simplicity of genetic modifications and well-established cancer models, zebrafish may be one of the most valuable animal models $[116,117]$. Additionally, the animal model gives the opportunity to deeply investigate the relationship between KYNA, carcinogenesis and the activity of the immune system.

\section{Dynamics and scheme of KYNA changes during cancer promotion and progression and potential changes during cancer therapy}

If KYNA promotes carcinogenesis and cancer progression, its supplementation and production should be decreased or inhibited. Decrease of KYNA supply in human daily diet seems not to be difficult, as only a few food products contain a significant amount of this compound, including chestnut honey and other honey, bee products, fresh broccoli and potato $[25,118]$. On the other hand, decrease of endogenous KYNA production may be also achieved by administration of KATs inhibitors. Although potent inhibitors of KATs are currently tested in the treatment of some brain disorders including Alzheimer's disease and dementia, the use of KAT inhibitors in anticancer therapy has not been studied $[119,120]$. Both strategies are possible for immediate implementation.

Assuming anticancer activity of KYNA, there are many theoretical possibilities to introduce KYNA as a supportive agent to anticancer therapy. Taking into consideration the knowledge about KYNA content in food products [25, 118], KYNA supplementation may be easily increased by 
diet modification. Interestingly, the anticancer potential of Mediterranean diet, considered rich in KYNA, has been already postulated [121]. Moreover, KYNA level in cancer tissue may be easily increased locally by direct application and may be used topically in the skin, oral cavity, eye, vagina or bladder. It should be noted that KYNA has been previously administrated to the human skin by topical application of cream with no observed side effects [122]. KYNA may be also administered orally leading to increase of KYNA level in gastrointestinal tract. In addition, it is easily absorbed and distributed to peripheral organs [25]. KYNA can also be administered intravenously even at high doses due to its low toxicity. Previous studies revealed that KYNA was non-toxic for rodents after continuous 6-h-long intravenous infusion of tested compound in a dose of $100 \mathrm{mg} / \mathrm{kg} / \mathrm{h}$ [123]. Similarly, KYNA administered in this mode could be used during the cycle of chemotherapy. Importantly, there are some studies that confirmed the beneficial effect of KYNA on anticancer activity of drugs commonly used in standard chemotherapy $[37,71]$. However, further studies are necessary to verify whether cancer tissue may accumulate KYNA or not and therefore, to choose the most effective mode of administration in anticancer therapy. Potential use of KYNA in therapy of brain tumours, especially glioblastoma, needs special attention. In vitro experiments did not clarify whether KYNA has a pro-carcinogenic or antiproliferative potential [37, 62]. Importantly, KYNA does not cross the brain-blood barrier and continuous long-lasting subdural infusion of high doses of KYNA increased the risk of myelin damage and myelin loss [124].

There is also a possibility that KYNA does not exert any activity during cancer promotion and progression and we should consider whether the previous results show specific effects of KYNA activity or non-specific effects of modified cancer cells' metabolism. KYNA is only one of the elements of kynurenine pathway. Kynurenine pathway produces several biologically active metabolites and plays various functions in the organism including detoxification of excess tryptophan and control of its plasma availability, regulation of hepatic heme biosynthesis, regulatory role in organism via niacin and $\mathrm{NAD}^{+}$synthesis [3]. Kynurenine pathway directly affects metabolic activity and in the same way may affect metabolism of cancer cells. All important redox cofactors $\mathrm{NAD}^{+}$and $\mathrm{NADP}^{+}$play the crucial role in various essential cellular processes, including energy metabolism, cell proliferation, DNA repair and apoptosis [3, 125]. Depletion of $\mathrm{NAD}^{+}$leads to inhibition of glycolysis, activity of citric acid cycle and oxidative phosphorylation, thus, the process of $\mathrm{NAD}^{+}$synthesis is an attractive molecular target for anticancer therapy. Previous studies revealed that depletion of $\mathrm{NAD}^{+}$in cancer cells results in dysfunction of antioxidant defense system, inhibition of proliferation and apoptosis interacting with MAPK and p53 signalling pathways [125]. It cannot be excluded that differences in KYNA concentrations in physiological fluids in cancer patients vs. healthy control group may not prove any KYNA activity towards the tumour cells, but the observed effect is only the body's response to the ongoing cancer process. Importantly, experimentally increased KYNA concentration may also affect the balance of biochemical reactions and in a non-specific manner KYNA may change the activity of cancer cells. The genetic manipulations or chemical inhibition of downstream reactions of kynurenine pathway leading to changes in $\mathrm{NAD}^{+}$level without any impact on KYNA synthesis would clarify whether KYNA or disruption of NAD ${ }^{+}$ synthesis plays a crucial role in cancer promotion and progression. Taking those into consideration, the potential use of KYNA as a diagnostic/prognostic marker in carcinogenesis or cancer therapy should be excessively investigated. Unfortunately, there are no studies describing the dynamics of changes in the level of KYNA and other KYN metabolites during the cancer treatment so far.

Summing up, there is a need for further studies and new data which will help to solve the dilemma of the role of KYNA in cancer in an unambiguous manner.

Acknowledgements We gratefully acknowledge the contribution of the late Prof. Grażyna Rajtar-Cynke to this paper. This study was supported by National Science Centre, Poland 2011/01/N/NZ4/01131 (DEC-2011/01/N/NZ4/01131) and 2015/17/D/NZ7/02170 (DEC2015/17/D/NZ7/02170). The results shown in this review are in part based upon data generated by the TCGA Research Network: https:// www.cancer.gov/tcga.

\section{Compliance with ethical standards}

Conflict of interest The authors declare that they have no conflict of interest.

Open Access This article is distributed under the terms of the Creative Commons Attribution 4.0 International License (http://creativeco mmons.org/licenses/by/4.0/), which permits unrestricted use, distribution, and reproduction in any medium, provided you give appropriate credit to the original author(s) and the source, provide a link to the Creative Commons license, and indicate if changes were made.

\section{References}

1. Hendrikx T, Schnabl B (2019) Indoles: metabolites produced by intestinal bacteria capable of controlling liver disease manifestation. J Intern Med 286(1):32-40

2. Peters JC (1991) Tryptophan nutrition and metabolism: an overview. Adv Exp Med Biol 294:345-358

3. Badawy AA (2017) Kynurenine pathway of tryptophan metabolism: regulatory and functional aspects. Int J Tryptophan Res 10:1178646917691938. https://doi.org/10.1177/1178646917 691938

4. Adams S, Braidy N, Bessede A, Brew BJ, Grant R, Teo C, Guillemin GJ (2012) The kynurenine pathway in brain tumor 
pathogenesis. Cancer Res 72(22):5649-5657. https://doi. org/10.1158/0008-5472.can-12-0549

5. Platten M, Nollen EAA, Rohrig UF, Fallarino F, Opitz CA (2019) Tryptophan metabolism as a common therapeutic target in cancer, neurodegeneration and beyond. Nat Rev Drug Discov 18(5):379-401

6. Theate I, van Baren N, Pilotte L, Moulin P, Larrieu P, Renauld JC, Herve C, Gutierrez-Roelens I, Marbaix E, Sempoux C, Van den Eynde BJ (2015) Extensive profiling of the expression of the indoleamine 2,3-dioxygenase 1 protein in normal and tumoral human tissues. Cancer Immunol Res 3(2):161-172. https://doi. org/10.1158/2326-6066.cir-14-0137

7. Okuno E, Nakamura M, Schwarcz R (1991) Two kynurenine aminotransferases in human brain. Brain Res 542(2):307-312

8. Han Q, Cai T, Tagle DA, Li J (2010) Thermal stability, $\mathrm{pH}$ dependence and inhibition of four murine kynurenine aminotransferases. BMC Biochem 11:19. https://doi. org/10.1186/1471-2091-11-19

9. Stone TW (1993) Neuropharmacology of quinolinic and kynurenic acids. Pharmacol Rev 45(3):309-379

10. Stone TW (2001) Kynurenic acid antagonists and kynurenine pathway inhibitors. Expert Opin Investig Drugs 10(4):633-645. https://doi.org/10.1517/13543784.10.4.633

11. Scharfman HE, Goodman JH, Schwarcz R (2000) Electrophysiological effects of exogenous and endogenous kynurenic acid in the rat brain: studies in vivo and in vitro. Amino Acids 19(1):283-297

12. Carpenedo R, Pittaluga A, Cozzi A, Attucci S, Galli A, Raiteri M, Moroni F (2001) Presynaptic kynurenate-sensitive receptors inhibit glutamate release. Eur J Neurosci 13(11):2141-2147

13. Erhardt S, Oberg H, Engberg G (2001) Pharmacologically elevated levels of endogenous kynurenic acid prevent nicotine-induced activation of nigral dopamine neurons. Naunyn Schmiedeberg's Arch Pharmacol 363(1):21-27

14. Vohra M, Lemieux GA, Lin L, Ashrafi K (2018) Kynurenic acid accumulation underlies learning and memory impairment associated with aging. Genes Dev 32(1):14-19. https://doi.org/10.1101/ gad.307918.117

15. Kozak R, Campbell BM, Strick CA, Horner W, Hoffmann WE, Kiss T, Chapin DS, McGinnis D, Abbott AL, Roberts BM, Fonseca K, Guanowsky V, Young DA, Seymour PA, Dounay A, Hajos M, Williams GV, Castner SA (2014) Reduction of brain kynurenic acid improves cognitive function. $\mathrm{J}$ Neurosci 34(32):10592-10602. https://doi.org/10.1523/jneur osci.1107-14.2014

16. Swartz KJ, Matson WR, MacGarvey U, Ryan EA, Beal MF (1990) Measurement of kynurenic acid in mammalian brain extracts and cerebrospinal fluid by high-performance liquid chromatography with fluorometric and coulometric electrode array detection. Anal Biochem 185(2):363-376

17. Rejdak R, Zarnowski T, Turski WA, Kocki T, Zagorski Z, Zrenner E, Schuettauf F (2003) Alterations of kynurenic acid content in the retina in response to retinal ganglion cell damage. Vis Res 43(5):497-503

18. Milart P, Urbańska EM, Turski WA, Paszkowski T, Sikorski R (1999) Intrapartum levels of endogenous glutamate antagonistkynurenic acid in amniotic fluid, umbilical and maternal blood. Neurosci Res Commun 24:173-178

19. Milart P, Paluszkiewicz P, Dobrowolski P, Tomaszewska E, Smolinska K, Debinska I, Gawel K, Walczak K, Bednarski J, Turska M, Raban M, Kocki T, Turski WA (2019) Kynurenic acid as the neglected ingredient of commercial baby formulas. Sci Rep 9(1):6108. https://doi.org/10.1038/s41598-019-42646-4

20. Parada-Turska J, Rzeski W, Zgrajka W, Majdan M, KandeferSzerszen M, Turski W (2006) Kynurenic acid, an endogenous constituent of rheumatoid arthritis synovial fluid, inhibits proliferation of synoviocytes in vitro. Rheumatol Int 26(5):422426. https://doi.org/10.1007/s00296-005-0057-4

21. Kuc D, Rahnama M, Tomaszewski T, Rzeski W, Wejksza K, Urbanik-Sypniewska T, Parada-Turska J, Wielosz M, Turski WA (2006) Kynurenic acid in human saliva-does it influence oral microflora? Pharmacol Rep 58(3):393-398

22. Paluszkiewicz P, Zgrajka W, Saran T, Schabowski J, Piedra JL, Fedkiv O, Rengman S, Pierzynowski SG, Turski WA (2009) High concentration of kynurenic acid in bile and pancreatic juice. Amino Acids 37(4):637-641. https://doi.org/10.1007/ s00726-008-0183-x

23. Kuc D, Zgrajka W, Parada-Turska J, Urbanik-Sypniewska T, Turski WA (2008) Micromolar concentration of kynurenic acid in rat small intestine. Amino Acids 35(2):503-505. https://doi. org/10.1007/s00726-007-0631-z

24. Walczak K, Dabrowski W, Langner E, Zgrajka W, Pilat J, Kocki T, Rzeski W, Turski WA (2011) Kynurenic acid synthesis and kynurenine aminotransferases expression in colon derived normal and cancer cells. Scand J Gastroenterol 46(7-8):903-912. https://doi.org/10.3109/00365521.2011.579159

25. Turski MP, Turska M, Zgrajka W, Kuc D, Turski WA (2009) Presence of kynurenic acid in food and honeybee products. Amino Acids 36(1):75-80. https://doi.org/10.1007/s0072 6-008-0031-z

26. Turski MP, Turska M, Zgrajka W, Bartnik M, Kocki T, Turski WA (2011) Distribution, synthesis, and absorption of kynurenic acid in plants. Planta Med 77(8):858-864. https://doi. org/10.1055/s-0030-1250604

27. Kaszaki J, Palasthy Z, Erczes D, Racz A, Torday C, Varga G, Vecsei L, Boros M (2008) Kynurenic acid inhibits intestinal hypermotility and xanthine oxidase activity during experimental colon obstruction in dogs. Neurogastroenterol Motil 20(1):5362. https://doi.org/10.1111/j.1365-2982.2007.00989.x

28. Varga G, Erces D, Fazekas B, Fulop M, Kovacs T, Kaszaki J, Fulop F, Vecsei L, Boros M (2010) N-Methyl-D-aspartate receptor antagonism decreases motility and inflammatory activation in the early phase of acute experimental colitis in the rat. Neurogastroenterol Motil 22(2):217-225e268. https://doi.org/10.11 11/j.1365-2982.2009.01390.x

29. Cosi C, Mannaioni G, Cozzi A, Carla V, Sili M, Cavone L, Maratea D, Moroni F (2011) G-protein coupled receptor 35 (GPR35) activation and inflammatory pain: studies on the antinociceptive effects of kynurenic acid and zaprinast. Neuropharmacology 60(7-8):1227-1231. https://doi.org/10.1016/j.neuro pharm.2010.11.014

30. Glavin GB, Pinsky C, Bose R (1990) Gastrointestinal effects of contaminated mussels and putative antidotes thereof. Canada Dis Wkly Rep 16(Suppl 1E):111-115

31. Glavin GB, Pinsky C (1989) Kynurenic acid attenuates experimental ulcer formation and basal gastric acid secretion in rats. Res Commun Chem Pathol Pharmacol 64(1):111-119

32. Glavin GB, Bose R, Pinsky C (1989) Kynurenic acid protects against gastroduodenal ulceration in mice injected with extracts from poisonous Atlantic shellfish. Prog Neuropsychopharmacol Biol Psychiatry 13(3-4):569-572

33. Pawlak K, Mysliwiec M, Pawlak D (2010) Kynurenine pathway-a new link between endothelial dysfunction and carotid atherosclerosis in chronic kidney disease patients. Adv Med Sci 55(2):196-203. https://doi.org/10.2478/v10039-010-0015-6

34. Lugo-Huitron R, Blanco-Ayala T, Ugalde-Muniz P, CarrilloMora P, Pedraza-Chaverri J, Silva-Adaya D, Maldonado PD, Torres I, Pinzon E, Ortiz-Islas E, Lopez T, Garcia E, Pineda B, Torres-Ramos M, Santamaria A, La Cruz VP (2011) On the antioxidant properties of kynurenic acid: free radical scavenging activity and inhibition of oxidative stress. Neurotoxicol Teratol 33(5):538-547. https://doi.org/10.1016/j.ntt.2011.07.002 
35. Marciniak S, Wnorowski A, Smolińska K, Walczyna B, Turski W, Kocki T, Paluszkiewicz P, Parada-Turska J (2018) Kynurenic acid protects against thioacetamide-induced liver injury in rats. Anal Cell Pathol (Amst) 2018:1270483. https:// doi.org/10.1155/2018/1270483

36. Gołyski J (2013) Kwas kynureninowy u chorych z gruczolakorakiem jelita grubego Kynurenic acid in patients with colon adenocarcinoma. PhD Thesis, Medical University of Lublin, Poland

37. Walczak K, Deneka-Hannemann S, Jarosz B, Zgrajka W, Stoma F, Trojanowski T, Turski WA, Rzeski W (2014) Kynurenic acid inhibits proliferation and migration of human glioblastoma T98G cells. Pharmacol Rep 66(1):130-136. https://doi. org/10.1016/j.pharep.2013.06.007

38. Walczak K, Zurawska M, Kis J, Starownik R, Zgrajka W, Bar K, Turski WA, Rzeski W (2012) Kynurenic acid in human renal cell carcinoma: its antiproliferative and antimigrative action on Caki-2 cells. Amino Acids 43(4):1663-1670. https://doi. org/10.1007/s00726-012-1247-5

39. Tankiewicz A, Dziemianczyk D, Buczko P, Szarmach IJ, Grabowska SZ, Pawlak D (2006) Tryptophan and its metabolites in patients with oral squamous cell carcinoma: preliminary study. Adv Med Sci 51(Suppl 1):221-224

40. Adams S, Teo C, McDonald KL, Zinger A, Bustamante S, Lim CK, Sundaram G, Braidy N, Brew BJ, Guillemin GJ (2014) Involvement of the kynurenine pathway in human glioma pathophysiology. PLoS One 9(11):e112945. https://doi. org/10.1371/journal.pone.0112945

41. Zdzisinska B, Wejksza K, Walter-Croneck A, Turski WA, Kandefer-Szerszen M (2010) Kynurenic acid in blood and bone marrow plasma of monoclonal gammopathy of undetermined significance (MGUS) and multiple myeloma (MM) patients. Leuk Res 34(1):38-45. https://doi.org/10.1016/j.leukr es.2009.06.015

42. Fotopoulou C, Sehouli J, Pschowski R, Von Haehling S, Domanska G, Braicu EI, Fusch G, Reinke P, Schefold JC (2011) Systemic changes of tryptophan catabolites via the indoleamine-2,3-dioxygenase pathway in primary cervical cancer. Anticancer Res 31(8):2629-2635

43. Sagan D, Kocki T, Kocki J, Szumilo J (2012) Serum kynurenic acid: possible association with invasiveness of non-small cell lung cancer. Asian Pac J Cancer Prev 13(9):4241-4244

44. Berthon C, Fontenay M, Corm S, Briche I, Allorge D, Hennart B, Lhermitte M, Quesnel B (2013) Metabolites of tryptophan catabolism are elevated in sera of patients with myelodysplastic syndromes and inhibit hematopoietic progenitor amplification. Leuk Res 37(5):573-579. https://doi.org/10.1016/j.leukr es.2013.02.001

45. Sagan D, Kocki T, Patel S, Kocki J (2015) Utility of kynurenic acid for non-invasive detection of metastatic spread to lymph nodes in non-small cell lung cancer. Int J Med Sci 12(2):146153. https://doi.org/10.7150/ijms. 7541

46. Fujinaga T, Nakamura J, Sangen H, Ohkawa T, Kido R (1980) A new method to determine urinary quinoline compounds in patients with bladder cancer. Invest Urol 17(5):416-418

47. DeGeorge FV, Brown RR (1970) Differences in tryptophan metabolism between breast cancer patients with and without cancer at other sites. Cancer 26(4):767-770

48. Teulings FA, Peters HA, Hop WC, Fokkens W, Haije WG, Portengen H, van der Werf-Messing B (1978) A new aspect of the urinary excretion of tryptophan metabolites in patients with cancer of the bladder. Int J Cancer 21(2):140-146

49. Bryan GT, Brown RR, Price JM (1964) Mouse bladder carcinogenicity of certain tryptophan metabolites and other aromatic nitrogen compounds suspended in cholesterol. Cancer Res 24:596-602
50. Davis HL Jr, Brown RR, Leklem J, Carlson IH (1973) Tryptophan metabolism in breast cancer. Correlation with urinary steroid excretion. Cancer 31(5):1061-1064

51. Gailani S, Murphy G, Kenny G, Nussbaum A, Silvernail P (1973) Studies on tryptophan metabolism in patients with bladder cancer. Cancer Res 33(5):1071-1077

52. Gailani S, Ezdinli E, Nussbaum A, Silvernail P, Elias EG (1974) Studies on tryptophan metabolism in patients with lymphoma. Cancer Res 34(7):1664-1667

53. Gkotsos G, Virgiliou C, Lagoudaki I, Sardeli C, Raikos N, Theodoridis G, Dimitriadis G (2017) The role of sarcosine, uracil, and kynurenic acid metabolism in urine for diagnosis and progression monitoring of prostate cancer. Metabolites 7(1). https://doi. org/10.3390/metabo7010009

54. Vezzani A, Gramsbergen JB, Versari P, Stasi MA, Procaccio F, Schwarcz R (1990) Kynurenic acid synthesis by human glioma. J Neurol Sci 99(1):51-57

55. Kocki T, Dolinska M, Dybel A, Urbanska EM, Turski WA, Albrecht J (2002) Regulation of kynurenic acid synthesis in C6 glioma cells. J Neurosci Res 68(5):622-626. https://doi. org/10.1002/jnr.10243

56. Turski MP, Kaminski P, Zgrajka W, Turska M, Turski WA (2012) Potato-an important source of nutritional kynurenic acid. Plant Foods Hum Nutr (Dordrecht, Netherlands) 67(1):17-23. https:// doi.org/10.1007/s11130-012-0283-3

57. Turska M, Pelak J, Turski MP, Kocki T, Dukowski P, Plech T, Turski W (2018) Fate and distribution of kynurenic acid administered as beverage. Pharmacol Rep 70(6):1089-1096. https:// doi.org/10.1016/j.pharep.2018.05.011

58. Gao J, Xu K, Liu H, Liu G, Bai M, Peng C, Li T, Yin Y (2018) Impact of the gut microbiota on intestinal immunity mediated by tryptophan metabolism. Front Cell Infect Microbiol 8:13. https ://doi.org/10.3389/fcimb.2018.00013

59. Wirthgen E, Hoeflich A, Rebl A, Gunther J (2017) Kynurenic acid: the Janus-faced role of an immunomodulatory tryptophan metabolite and its link to pathological conditions. Front Immunol 8:1957. https://doi.org/10.3389/fimmu.2017.01957

60. Pawlak D, Pawlak K, Malyszko J, Mysliwiec M, Buczko W (2001) Accumulation of toxic products degradation of kynurenine in hemodialyzed patients. Int Urol Nephrol 33(2):399-404

61. Pawlak D, Tankiewicz A, Mysliwiec P, Buczko W (2002) Tryptophan metabolism via the kynurenine pathway in experimental chronic renal failure. Nephron 90(3):328-335. https://doi. org/10.1159/000049069

62. Di Serio C, Cozzi A, Angeli I, Doria L, Micucci I, Pellerito S, Mirone P, Masotti G, Moroni F, Tarantini F (2005) Kynurenic acid inhibits the release of the neurotrophic fibroblast growth factor (FGF)-1 and enhances proliferation of glia cells, in vitro. Cell Mol Neurobiol 25(6):981-993. https://doi.org/10.1007/ s10571-005-8469-y

63. Walczak K, Turski WA, Rzeski W (2012) Kynurenic acid enhances expression of $\mathrm{p} 21 \mathrm{Waf} 1 / \mathrm{Cip} 1$ in colon cancer HT-29 cells. Pharmacol Rep 64(3):745-750

64. Perkins MN, Stone TW (1982) An iontophoretic investigation of the actions of convulsant kynurenines and their interaction with the endogenous excitant quinolinic acid. Brain Res 247(1):184-187

65. Birch PJ, Grossman CJ, Hayes AG (1988) Kynurenic acid antagonises responses to NMDA via an action at the strychnine-insensitive glycine receptor. Eur J Pharmacol 154(1):85-87

66. Hilmas C, Pereira EF, Alkondon M, Rassoulpour A, Schwarcz R, Albuquerque EX (2001) The brain metabolite kynurenic acid inhibits alpha7 nicotinic receptor activity and increases nonalpha7 nicotinic receptor expression: physiopathological implications. J Neurosci 21(19):7463-7473 
67. Wang J, Simonavicius N, Wu X, Swaminath G, Reagan J, Tian H, Ling L (2006) Kynurenic acid as a ligand for orphan $G$ proteincoupled receptor GPR35. J Biol Chem 281(31):22021-22028. https://doi.org/10.1074/jbc.M603503200

68. DiNatale BC, Murray IA, Schroeder JC, Flaveny CA, Lahoti TS, Laurenzana EM, Omiecinski CJ, Perdew GH (2010) Kynurenic acid is a potent endogenous aryl hydrocarbon receptor ligand that synergistically induces interleukin- 6 in the presence of inflammatory signaling. Toxicol Sci 115(1):89-97. https://doi. org/10.1093/toxsci/kfq024

69. Maaetoft-Udsen K, Shimoda LM, Frokiaer H, Turner H (2012) Aryl hydrocarbon receptor ligand effects in RBL2H3 cells. J Immunotoxicol 9(3):327-337. https://doi.org/10.3109/15476 91x.2012.661802

70. Stepulak A, Sifringer M, Rzeski W, Endesfelder S, Gratopp A, Pohl EE, Bittigau P, Felderhoff-Mueser U, Kaindl AM, Buhrer C, Hansen HH, Stryjecka-Zimmer M, Turski L, Ikonomidou C (2005) NMDA antagonist inhibits the extracellular signal-regulated kinase pathway and suppresses cancer growth. Proc Natl Acad Sci USA 102(43):15605-15610. https://doi.org/10.1073/ pnas.0507679102

71. Rzeski W, Turski L, Ikonomidou C (2001) Glutamate antagonists limit tumor growth. Proc Natl Acad Sci USA 98(11):6372-6377. https://doi.org/10.1073/pnas.091113598

72. Pillai S, Chellappan S (2012) alpha7 nicotinic acetylcholine receptor subunit in angiogenesis and epithelial to mesenchymal transition. Curr Drug Targets 13(5):671-679

73. Arias HR, Richards VE, Ng D, Ghafoori ME, Le V, Mousa SA (2009) Role of non-neuronal nicotinic acetylcholine receptors in angiogenesis. Int J Biochem Cell Biol 41(7):1441-1451. https:// doi.org/10.1016/j.biocel.2009.01.013

74. Tu CC, Huang CY, Cheng WL, Hung CS, Chang YJ, Wei PL (2016) Silencing A7-nAChR levels increases the sensitivity of gastric cancer cells to ixabepilone treatment. Tumour Biol 37(7):9493-9501. https://doi.org/10.1007/s13277-015-4751-x

75. Gahring LC, Myers EJ, Dunn DM, Weiss RB, Rogers SW (2017) Lung epithelial response to cigarette smoke and modulation by the nicotinic alpha 7 receptor. PLoS One 12(11):e0187773. https ://doi.org/10.1371/journal.pone.0187773

76. Fujii-Kuriyama Y, Kawajiri K (2010) Molecular mechanisms of the physiological functions of the aryl hydrocarbon (dioxin) receptor, a multifunctional regulator that senses and responds to environmental stimuli. Proc Japan Acad Ser B Phys Biol Sci 86(1):40-53

77. Kolluri SK, Jin UH, Safe S (2017) Role of the aryl hydrocarbon receptor in carcinogenesis and potential as an anti-cancer drug target. Arch Toxicol 91(7):2497-2513. https://doi.org/10.1007/ s00204-017-1981-2

78. Dever DP, Opanashuk LA (2012) The aryl hydrocarbon receptor contributes to the proliferation of human medulloblastoma cells. Mol Pharmacol 81(5):669-678. https://doi.org/10.1124/ mol.111.077305

79. Andersson P, McGuire J, Rubio C, Gradin K, Whitelaw ML, Pettersson S, Hanberg A, Poellinger L (2002) A constitutively active dioxin/aryl hydrocarbon receptor induces stomach tumors. Proc Natl Acad Sci USA 99(15):9990-9995. https://doi.org/10.1073/ pnas. 152706299

80. Xue P, Fu J, Zhou Y (2018) The aryl hydrocarbon receptor and tumor immunity. Front Immunol 9:286. https://doi.org/10.3389/ fimmu.2018.00286

81. Platten M, von Knebel Doeberitz N, Oezen I, Wick W, Ochs K (2014) Cancer immunotherapy by targeting IDO1/TDO and their downstream effectors. Front Immunol 5:673. https://doi. org/10.3389/fimmu.2014.00673

82. Opitz CA, Litzenburger UM, Sahm F, Ott M, Tritschler I, Trump S, Schumacher T, Jestaedt L, Schrenk D, Weller M, Jugold M,
Guillemin GJ, Miller CL, Lutz C, Radlwimmer B, Lehmann I, von Deimling A, Wick W, Platten M (2011) An endogenous tumour-promoting ligand of the human aryl hydrocarbon receptor. Nature 478(7368):197-203. https://doi.org/10.1038/natur e10491

83. Hall JM, Barhoover MA, Kazmin D, McDonnell DP, Greenlee WF, Thomas RS (2010) Activation of the aryl-hydrocarbon receptor inhibits invasive and metastatic features of human breast cancer cells and promotes breast cancer cell differentiation. Mol Endocrinol (Baltimore, Md) 24(2):359-369. https:// doi.org/10.1210/me.2009-0346

84. Gluschnaider U, Hidas G, Cojocaru G, Yutkin V, Ben-Neriah Y, Pikarsky E (2010) beta-TrCP inhibition reduces prostate cancer cell growth via upregulation of the aryl hydrocarbon receptor. PLoS One 5(2):e9060. https://doi.org/10.1371/journ al.pone. 0009060

85. Fan Y, Boivin GP, Knudsen ES, Nebert DW, Xia Y, Puga A (2010) The aryl hydrocarbon receptor functions as a tumor suppressor of liver carcinogenesis. Cancer Res 70(1):212-220. https ://doi.org/10.1158/0008-5472.can-09-3090

86. Kawajiri K, Kobayashi Y, Ohtake F, Ikuta T, Matsushima Y, Mimura J, Pettersson S, Pollenz RS, Sakaki T, Hirokawa T, Akiyama T, Kurosumi M, Poellinger L, Kato S, Fujii-Kuriyama Y (2009) Aryl hydrocarbon receptor suppresses intestinal carcinogenesis in ApcMin/+ mice with natural ligands. Proc Natl Acad Sci USA 106(32):13481-13486. https://doi.org/10.1073/ pnas.0902132106

87. Contador-Troca M, Alvarez-Barrientos A, Barrasa E, RicoLeo EM, Catalina-Fernandez I, Menacho-Marquez M, Bustelo XR, Garcia-Borron JC, Gomez-Duran A, Saenz-Santamaria J, Fernandez-Salguero PM (2013) The dioxin receptor has tumor suppressor activity in melanoma growth and metastasis. Carcinogenesis 34(12):2683-2693. https://doi.org/10.1093/carcin/bgt24 8

88. Mutz CN, Schwentner R, Kauer MO, Katschnig AM, Kromp F, Aryee DN, Erhardt S, Goiny M, Alonso J, Fuchs D, Kovar H (2016) EWS-FLI1 impairs aryl hydrocarbon receptor activation by blocking tryptophan breakdown via the kynurenine pathway. FEBS Lett 590(14):2063-2075. https://doi. org/10.1002/1873-3468.12243

89. Sekine H, Mimura J, Oshima M, Okawa H, Kanno J, Igarashi K, Gonzalez FJ, Ikuta T, Kawajiri K, Fujii-Kuriyama Y (2009) Hypersensitivity of aryl hydrocarbon receptor-deficient mice to lipopolysaccharide-induced septic shock. Mol Cell Biol 29(24):6391-6400. https://doi.org/10.1128/mcb.00337-09

90. Baglole CJ, Maggirwar SB, Gasiewicz TA, Thatcher TH, Phipps RP, Sime PJ (2008) The aryl hydrocarbon receptor attenuates tobacco smoke-induced cyclooxygenase- 2 and prostaglandin production in lung fibroblasts through regulation of the NF-kappaB family member RelB. J Biol Chem 283(43):28944-28957. https ://doi.org/10.1074/jbc.M800685200

91. Zhang S, Patel A, Chu C, Jiang W, Wang L, Welty SE, Moorthy B, Shivanna B (2015) Aryl hydrocarbon receptor is necessary to protect fetal human pulmonary microvascular endothelial cells against hyperoxic injury: mechanistic roles of antioxidant enzymes and RelB. Toxicol Appl Pharmacol 286(2):92-101. https://doi.org/10.1016/j.taap.2015.03.023

92. Thatcher TH, Williams MA, Pollock SJ, McCarthy CE, Lacy SH, Phipps RP, Sime PJ (2016) Endogenous ligands of the aryl hydrocarbon receptor regulate lung dendritic cell function. Immunology 147(1):41-54. https://doi.org/10.1111/imm.12540

93. Roberts PJ, Der CJ (2007) Targeting the Raf-MEK-ERK mitogen-activated protein kinase cascade for the treatment of cancer. Oncogene 26(22):3291-3310. https://doi.org/10.1038/ sj.onc. 1210422 
94. Uwai Y, Honjo H, Iwamoto K (2012) Interaction and transport of kynurenic acid via human organic anion transporters hOAT1 and hOAT3. Pharmacol Res 65(2):254-260. https://doi.org/10.1016/j. phrs.2011.11.003

95. Weinstein JN, Collisson EA, Mills GB, Shaw KR, Ozenberger BA, Ellrott K, Shmulevich I, Sander C, Stuart JM (2013) The Cancer Genome Atlas Pan-Cancer analysis project. Nat Genet 45(10):1113-1120. https://doi.org/10.1038/ng.2764

96. GTEx Consortium; Laboratory, Data Analysis \&Coordinating Center (LDACC) - Analysis Working Group; Statistical Methods groups-Analysis Working Group; Enhancing GTEx (eGTEx) groups; NIH Common Fund; NIH/NCI; NIH/NHGRI; NIH/NIMH; NIH/NIDA; Biospecimen Collection Source SiteNDRI; Biospecimen Collection Source Site-RPCI; Biospecimen Core Resource-VARI; Brain Bank Repository-University of Miami Brain Endowment Bank; Leidos Biomedical—Project Management; ELSI Study; Genome Browser Data Integration \&Visualization-EBI; Genome Browser Data Integration \&Visualization-UCSC Genomics Institute, University of California Santa Cruz; Lead analysts:; Laboratory, Data Analysis \&Coordinating Center (LDACC):; NIH program management:; Biospecimen collection:; Pathology:; eQTL manuscript working group:, Battle A, Brown CD, Engelhardt BE, Montgomery SB (2017) Genetic effects on gene expression across human tissues. Nature 550(7675):204-213. https://doi.org/10.1038/nature24277

97. Speciale C, Hares K, Schwarcz R, Brookes N (1989) High-affinity uptake of L-kynurenine by a Na+-independent transporter of neutral amino acids in astrocytes. J Neurosci 9(6):2066-2072

98. Goldsmith ZG, Dhanasekaran DN (2007) G protein regulation of MAPK networks. Oncogene 26(22):3122-3142. https://doi. org/10.1038/sj.onc. 1210407

99. Walczak K, Turski WA, Rajtar G (2014) Kynurenic acid inhibits colon cancer proliferation in vitro: effects on signaling pathways. Amino Acids 46(10):2393-2401. https://doi.org/10.1007/s0072 6-014-1790-3

100. Sun Y, Liu WZ, Liu T, Feng X, Yang N, Zhou HF (2015) Signaling pathway of MAPK/ERK in cell proliferation, differentiation, migration, senescence and apoptosis. J Recept Signal Transduct Res 35(6):600-604. https://doi.org/10.3109/10799 893.2015.1030412

101. Shevtsov SP, Haq S, Force T (2006) Activation of beta-catenin signaling pathways by classical G-protein-coupled receptors: mechanisms and consequences in cycling and non-cycling cells. Cell Cycle (Georgetown, Tex) 5(20):2295-2300. https://doi. org/10.4161/cc.5.20.3357

102. Silva-Garcia O, Valdez-Alarcon JJ, Baizabal-Aguirre VM (2014) The Wnt/beta-catenin signaling pathway controls the inflammatory response in infections caused by pathogenic bacteria. Mediat Inflamm 2014:310183. https://doi.org/10.1155/2014/310183

103. Tigyi GJ, Yue J, Norman DD, Szabo E, Balogh A, Balazs L, Zhao G, Lee SC (2019) Regulation of tumor cell - Microenvironment interaction by the autotaxin-lysophosphatidic acid receptor axis. Adv Biol Regul 71:183-193. https://doi.org/10.1016/j.jbior .2018.09.008

104. Savant SS, Sriramkumar S, O'Hagan HM (2018) The Role of Inflammation and Inflammatory Mediators in the Development, Progression, Metastasis, and Chemoresistance of Epithelial Ovarian Cancer. Cancers (Basel) 10(8). https://doi.org/10.3390/ cancers 10080251

105. Davies LC, Rice CM, McVicar DW, Weiss JM (2018) Diversity and environmental adaptation of phagocytic cell metabolism. J Leukoc Biol. https://doi.org/10.1002/jlb.4ri0518-195r

106. van Belzen I, Kesmir C (2018) Immune biomarkers for predicting response to adoptive cell transfer as cancer treatment.
Immunogenetics 71(2):71-86. https://doi.org/10.1007/s0025 1-018-1083-1

107. Nie M, Balda MS, Matter K (2012) Stress- and Rho-activated $\mathrm{ZO}-1$-associated nucleic acid binding protein binding to $\mathrm{p} 21$ mRNA mediates stabilization, translation, and cell survival. Proc Natl Acad Sci USA 109(27):10897-10902. https://doi. org/10.1073/pnas.1118822109

108. Lin K, Jiang H, Zhang LL, Jiang Y, Yang YX, Qiu GD, She YQ, Zheng JT, Chen C, Fang L, Zhang SY (2018) Down-regulated LncRNA-HOTAIR suppressed colorectal cancer cell proliferation, invasion, and migration by mediating p21. Dig Dis Sci 63(9):2320-2331. https://doi.org/10.1007/s10620-018-5127-z

109. Zarubin T, Han J (2005) Activation and signaling of the $p 38$ MAP kinase pathway. Cell Res 15(1):11-18. https://doi. org/10.1038/sj.cr.7290257

110. Stramucci L, Pranteda A, Bossi G (2018) Insights of crosstalk between p53 protein and the MKK3/MKK6/p38 MAPK signaling pathway in cancer. Cancers 10(5). https://doi.org/10.3390/ cancers 10050131

111. Marciniak A, Turski W (2010) A novel medical use of kynurenic acid, its precursors and derivatives. International Patent WO20101 10689

112. Turski WA, Malaczewska J, Marciniak S, Bednarski J, Turski MP, Jablonski M, Siwicki AK (2014) On the toxicity of kynurenic acid in vivo and in vitro. Pharmacol Rep 66(6):11271133. https://doi.org/10.1016/j.pharep.2014.07.013

113. Dankers AC, Mutsaers HA, Dijkman HB, van den Heuvel LP, Hoenderop JG, Sweep FC, Russel FG, Masereeuw R (2013) Hyperuricemia influences tryptophan metabolism via inhibition of multidrug resistance protein 4 (MRP4) and breast cancer resistance protein (BCRP). Biochem Biophys Acta 1832(10):1715-1722. https://doi.org/10.1016/j.bbadi s.2013.05.002

114. Mutsaers HA, van den Heuvel LP, Ringens LH, Dankers AC, Russel FG, Wetzels JF, Hoenderop JG, Masereeuw R (2011) Uremic toxins inhibit transport by breast cancer resistance protein and multidrug resistance protein 4 at clinically relevant concentrations. PLoS One 6(4):e18438. https://doi.org/10.1371/journ al.pone. 0018438

115. Maliepaard M, Scheffer GL, Faneyte IF, van Gastelen MA, Pijnenborg AC, Schinkel AH, van De Vijver MJ, Scheper RJ, Schellens JH (2001) Subcellular localization and distribution of the breast cancer resistance protein transporter in normal human tissues. Cancer Res 61(8):3458-3464

116. Bootorabi F, Manouchehri H, Changizi R, Barker H, Palazzo E, Saltari A, Parikka M, Pincelli C, Aspatwar A (2017) Zebrafish as a model organism for the development of drugs for skin cancer. Int J Mol Sci 18(7). https://doi.org/10.3390/ijms18071550

117. Chen L, Groenewoud A, Tulotta C, Zoni E, Kruithof-de Julio M, van der Horst G, van der Pluijm G, Ewa Snaar-Jagalska B (2017) A zebrafish xenograft model for studying human cancer stem cells in distant metastasis and therapy response. Methods Cell Biol 138:471-496. https://doi.org/10.1016/bs.mcb.2016.10.009

118. Turski MCS, Turska M, Chwil M, Kocki T, Rajtar G, ParadaTurska J (2016) An exceptionally high content of kynurenic acid in chestnut honey and flowers of chestnut tree. J Food Compos Anal 48:67-72

119. Nematollahi A, Sun G, Jayawickrama GS, Hanrahan JR, Church WB (2016) Study of the activity and possible mechanism of action of a reversible inhibitor of recombinant human KAT-2: a promising lead in neurodegenerative and cognitive disorders. Molecules 21(7). https://doi.org/10.3390/molecules21070856

120. Bortz DM, Wu HQ, Schwarcz R, Bruno JP (2017) Oral administration of a specific kynurenic acid synthesis (KAT II) inhibitor attenuates evoked glutamate release in rat prefrontal cortex. 
Neuropharmacology 121:69-78. https://doi.org/10.1016/j.neuro pharm.2017.04.023

121. Kwan HY, Chao X, Su T, Fu X, Tse AK, Fong WF, Yu ZL (2017) The anticancer and antiobesity effects of Mediterranean diet. Crit Rev Food Sci Nutr 57(1):82-94. https://doi.org/10.1080/10408 398.2013.852510

122. Papp A, Hartwell R, Evans M, Ghahary A (2018) The safety and tolerability of topically delivered kynurenic acid in humans. A phase 1 randomized double-blind clinical trial. J Pharm Sci 107(6):1572-1576. https://doi.org/10.1016/j.xphs.2018.01.023

123. Marciniak A (2013) Rola kwasu kynureninowego w utrzymaniu integralności układu zewnątrzwydzielniczego trzustki w doświadczalnym ceruleinowym ostrym zapaleniu trzustki. Medical University of Lublin, Poland

124. Dabrowski W, Kwiecien JM, Rola R, Klapec M, Stanisz GJ, Kotlinska-Hasiec E, Oakden W, Janik R, Coote M, Frey BN, Turski WA (2015) Prolonged subdural infusion of kynurenic acid is associated with dose-dependent myelin damage in the rat spinal cord. PLoS One 10(11):e0142598. https://doi.org/10.1371/journ al.pone. 0142598

125. Kennedy BE, Sharif T, Martell E, Dai C, Kim Y, Lee PW, Gujar SA (2016) NAD(+) salvage pathway in cancer metabolism and therapy. Pharmacol Res 114:274-283. https://doi.org/10.1016/j. phrs.2016.10.027

126. Blanco Ayala T, Lugo Huitron R, Carmona Aparicio L, Ramirez Ortega D, Gonzalez Esquivel D, Pedraza Chaverri J, Perez de la Cruz G, Rios C, Schwarcz R, Perez de la Cruz V (2015) Alternative kynurenic acid synthesis routes studied in the rat cerebellum. Front Cell Neurosci 9:178. https://doi.org/10.3389/ fncel.2015.00178

127. Liao TL, Chen SC, Tzeng CR, Kao SH (2014) TCDD induces the hypoxia-inducible factor (HIF)-1alpha regulatory pathway in human trophoblastic JAR cells. Int J Mol Sci 15(10):1773317750. https://doi.org/10.3390/ijms 151017733

128. Tsai CF, Hsieh TH, Lee JN, Hsu CY, Wang YC, Lai FJ, Kuo KK, Wu HL, Tsai EM, Kuo PL (2014) Benzyl butyl phthalate induces migration, invasion, and angiogenesis of Huh7 hepatocellular carcinoma cells through nongenomic AhR/G-protein signaling. BMC Cancer 14:556. https://doi.org/10.1186/1471-2407-14-556

129. Hubbard TD, Murray IA, Perdew GH (2015) Indole and tryptophan metabolism: endogenous and dietary routes to Ah receptor activation. Drug Metab Dispos 43(10):1522-1535. https://doi. org/10.1124/dmd.115.064246

130. Mackenzie AE, Lappin JE, Taylor DL, Nicklin SA, Milligan G (2011) GPR35 as a novel therapeutic target. Front Endocrinol 2:68. https://doi.org/10.3389/fendo.2011.00068

131. Tang Z, Li C, Kang B, Gao G, Li C, Zhang Z (2017) GEPIA: a web server for cancer and normal gene expression profiling and interactive analyses. Nucleic Acids Res 45(W1):W98-w102. https://doi.org/10.1093/nar/gkx247

Publisher's Note Springer Nature remains neutral with regard to jurisdictional claims in published maps and institutional affiliations. 